\title{
Photocatalytic Detoxification of Antibiotic- and Bacteria-Contaminated Water using Cobalt-Doped Ni-Zn Ferrites Magnetic Separable Nanopowders
}

\section{Faisal Suleiman Mustafa}

Eastern Mediterranean University: Dogu Akdeniz Universitesi

Akeem Adeyemi Oladipo ( $\square$ akeem.oladipo@gmail.com )

Dogu Akdeniz Universitesi https://orcid.org/0000-0003-3715-5922

\section{Zirar M Mizwari}

Erbil Polytechnic University

\section{Mustafa Gazi}

Eastern Mediterranean University: Dogu Akdeniz Universitesi

\section{Research Article}

Keywords: Environmental pollution, antibiotic decontamination, Ni-Zn spinel ferrites, bactericidal efficiency, UV-photocatalysis, Cobalt doped nanopowders

Posted Date: August 30th, 2021

DOl: https://doi.org/10.21203/rs.3.rs-650772/v1

License: (c) (i) This work is licensed under a Creative Commons Attribution 4.0 International License. Read Full License 


\section{Photocatalytic Detoxification of Antibiotic- and Bacteria-Contaminated Water 2 using Cobalt-Doped Ni-Zn Ferrites Magnetic Separable Nanopowders}

Faisal Suleiman Mustafa ${ }^{1}$, Akeem Adeyemi Oladipo $^{1 *}$, Zirar M Mizwari $^{2,3}$, Mustafa Gazi $^{1}$

${ }^{1}$ Polymeric Materials Research Laboratory, Department of Chemistry, Faculty of Arts and Sciences, Eastern Mediterranean University, Famagusta TR North Cyprus, via Mersin 10, Turkey.

${ }^{2}$ Department of Medical Laboratory Technology, Shaqlawa Technical College, Erbil Polytechnic University, Erbil, Iraq

${ }^{3}$ Rwandz Private Technical Institute, Erbil, Iraq.

*Corres. authors: akeem.oladipo@emu.edu.tr | akeem.oladipo@gmail.com (AA Oladipo) AA Oladipo: https://orcid.org/0000-0003-3715-5922

FS Mustafa: https://orcid.org/0000-0003-0685-0025

M Gazi: https://orcid.org/0000-0001-7736-752X

\section{Abstract}

Here, metronidazole (MZ) antibiotic degradation and bactericidal efficacy of $\mathrm{Co}-\mathrm{Ni}_{0.5} \mathrm{Zn}_{0.5} \mathrm{Fe}_{2} \mathrm{O}_{4}$ (Co-NZF) with and without photoactivation by UV light is reported as a viable cost-competitive water disinfection solution. Co-NZF has a total pore volume of $0.298 \mathrm{~cm}^{3} \mathrm{~g}^{-1}$, a specific surface area of $70.2 \mathrm{~m}^{2} \mathrm{~g}^{-1}$ and sufficiently high magnetic properties $(80.35 \mathrm{emu} \mathrm{g}$ ). After $360 \mathrm{~min}$ of $\mathrm{UV}$-assisted irradiation at $\mathrm{pH} 3,10 \mathrm{mg} \mathrm{Co}-\mathrm{NZF}$, and $4 \mathrm{mM} \mathrm{H}_{2} \mathrm{O}_{2}$, the maximum $\mathrm{MZ}$ degradation was reached $(92.8 \%)$. The adsorption result of $10 \mathrm{mg} \mathrm{Co-NZF}$ in the dark for $12 \mathrm{~h}$ resulted in $70.2 \% \mathrm{MZ}$ removal, whereas MZ self-degradation was significantly minimal in a blank trial. In the presence of interfering anions and very high molecular weight tylosin antibiotic, Co-NZF maintained 51.7-75.4\% degradation efficiency. The effect of the Co-NZF dosage on the viability of Staphylococcus aureus and Escherichia coli strains showed that $15 \mathrm{mg}$ of the catalyst was sufficient to cause bactericidal activity after $180 \mathrm{~min}$ in the presence of UV light, while $25 \mathrm{mg}$ is needed under dark conditions. In addition, when compared to Escherichia coli strains, Co-NZF showed higher inhibition against Staphylococcus aureus in time-kill experiments under dose variation.

Keywords: Environmental pollution; antibiotic decontamination; Ni-Zn spinel ferrites; bactericidal efficiency; UV-photocatalysis; Cobalt doped nanopowders 


\section{Introduction}

Pharmaceutical antibiotics are becoming increasingly important globally due to their effectiveness in preventing or treating infections in humans and promoting animal growth (Serna-Galvis et al. 2017; Tran et al. 2019; Azalok et al. 2021ab). The increasing demand for veterinary antibiotics is worrying (Roberts and Zembower 2021), considering the rise in the number of people owning pets like dogs and cats during this pandemic, numerous human diseases, and growing global demand for animal protein for human consumption. Since most antibiotics are poorly absorbed by humans and livestock, this widespread use of antibiotics raises the risk of significant quantities of residual antibiotics ending up in the environment ( $\mathrm{Li}$ et al.2015; Estrada-Flórez et al. 2020; Chan et al. 2020).

Antibiotic resistance bacteria and antibiotic-resistant genes are becoming more common as antibiotics and their residues become more prevalent in the ecosystem (Luo et al. 2010; Abureesh et al. 2018). This is in line with the findings of Luo et al. (2010), who noted that the relative abundance of antibiotic-resistant genes (i.e., sul1\&2/16S-rDNA) in the China Haihe River is linked to total sulfonamide antibiotic concentrations. The key threat posed by these antibioticresistant bacteria and genes is a rise in pathogenic bacteria, posing a serious threat to humans. According to the World Health Organization (WHO, 2019), at least 700,000 people die each year as a result of drug-resistant diseases, and the United States CDC (Centers for Disease Control and Prevention) estimates that at least 30,000 people die each year in the United States as a result of antibiotic-resistant diseases (Dadgostar 2019).

Metronidazole (MZ) is one of these antibiotics that is commonly used to treat anaerobic bacterial infections, various protozoa, and Giardia infections in dogs and cats, as well as being mixed with poultry and fish feeds to aid weight gain (Bashiri et al. 2020; Fakhravar et al. 2020; 
Azalok et al. 2021a). MZF has been detected at concentrations ranging from 0.65 to $28.4 \mu \mathrm{g} / \mathrm{L}$ in

61 surface water and groundwater in recent years (Oladipo et al. 2018). Its excessive use by humans

62 and pets, as well as its high solubility $\left(\sim 10 \mathrm{mg} \mathrm{L}^{-1}\right.$ at $25^{\circ} \mathrm{C}$ in water $)$ and emission of residues and

63 metabolites, has resulted in its saturation in the environment (Tran et al. 2019; Hena et al. 2020,

64 2021). The removal of MZ residues and metabolites from aqueous environments is critical because

65 antibiotic resistance caused by the overuse of antibiotics is becoming a global health threat,

66 resulting in higher medical costs and mortality (Varma et al. 2020a). Physical and biological

67 methods have been used in the past to eliminate antibiotics. However, physical methods such as

68 adsorption can adsorb the pollutant and then move it to an adsorbent surface, which involves more

69 disposal (Oladipo et al. 2018). MZ's antibacterial properties, complex structure, and high

70 molecular weight limit the effectiveness of biological methods for its removal.

71 Because of its low cost, higher performance, strong oxidation potential, and faster reaction

72 rates, semiconductor photocatalysis is a viable and environmentally friendly solution for removing

73 antibiotic and bacteria contamination from water (Aali et al. 2019; Asadi et al., 2019; Tran et al.

74 2019ab; Varma et al. 2020b; Azalok et al. 2021ab). In recent years, single metal oxide

75 semiconductors such as $\mathrm{In}_{2} \mathrm{O}_{3}, \mathrm{TiO}_{2}$ and $\mathrm{ZnO}$ have been widely applied and considered efficient

76 to eliminate hazardous contaminants in wastewater owing to their cost-effectiveness, oxidative

77 potential and catalytic stability for widespread environmental applications (Elmolla et al. 2010;

78 Bokare et al. 2013; Tran et al. 2019b). However, the wide bandgap (3.2 eV) and high

79 recombination rate of the aforementioned single metal oxide semiconductors limit their

80 photoresponses in the UV region (4-5\% of solar spectrum) and minimize photocatalytic reactions,

81 respectively (Oladipo et al. 2019; Zhao et al. 2020). Apart from that, their separation from the

82 reaction system after spent is a problem. 
In recent years, mixed metal oxide spinel ferrites $\left(\mathrm{M}_{x} \mathrm{M}_{1-x} \mathrm{Fe}_{2} \mathrm{O}_{4}\right.$, where $\mathrm{M}$ is a

84 different metal cation i.e. $\mathrm{Ni}, \mathrm{Mg}, \mathrm{Ca}, \mathrm{Zn}, \mathrm{Ag}, \mathrm{Co}, \mathrm{Cr}$ )-based semiconductors have sparked a lot of interest in the field of photocatalysis because of their diverse optoelectronic properties and

86 topological metal sites structure (Manikandan et al. 2015; Kefeni and Mamba 2020); and have

87 been applied to decompose varieties of organic pollutants and inactivate bacteria during water

88 treatment of wastewater (Chen et al. 2017; Asadi and Moeinpour 2019; Tsvetkov et al. 2019).

89 Particularly, spinel Ni-Zn ferrites are particularly appealing for wastewater decontamination

90 because of their small bandgap $(2-2.5 \mathrm{eV})$, intrinsic redox chemistry, tunable electronic properties,

91 and topologically organized metal sites (Qasim et al. 2015; Aali et al. 2019; Nag et al., 2020). Aali

92 et al. (2019) synthesized $\mathrm{Ni}_{0.5} \mathrm{Zn}_{0.5} \mathrm{Fe}_{2} \mathrm{O}_{4}$ photocatalyst using a solution combustion synthesis

93 technique and observed $85 \%$ methylene blue dye photodegradation and $100 \%$ bacteria growth

94 inhibition against $E$. coli and $S$. aureus strains, respectively, with a minimum inhibitory 95 concentration of $0.25 \mathrm{mg} / \mathrm{mL}$ and $0.125 \mathrm{mg} / \mathrm{mL}$.

Ferrites are also chemically stable, magnetically simple to separate, and inexpensive. It

97 was discovered that doping or combining with other metal oxide semiconductors improved the

98 ferrites' adsorption ability, specific surface area, and light-driven photoactivity (Qasim et al. 2015;

99 Ifebajo et al. 2020; Nag et al. 2020). Doping the photocatalyst with high conductivity metal ions

100 like Co, Ag, and Pt induces highly efficient electron mobility and delays the recombination step 101 of photo-generated electrons/holes, resulting in increased photocatalyst degradation operation 102 (Sinha 2021; Asadi and Moeinpour 2019; Chahal et al. 2020). For example, Sinha 2021 reported 103 that by doping Bismuth-based ferrite with Co dopant, the crystallite size of the nanostructured 104 material was reduced and the bandgap energy was increased from $2.07 \mathrm{eV}$ to $2.43 \mathrm{eV}$, resulting in 105 increased photocatalysis and remarkable optoelectronic activity. Motivated by the above 


\section{Experimental section}

\section{Reagents}

124 Analytical grade reagents were used without purification. Cobalt (II) nitrate hexahydrate $127\left(\mathrm{FeCl}_{3} \cdot 6 \mathrm{H}_{2} \mathrm{O}\right)$, acetic acid, metronidazole antibiotic $(\mathrm{MZ})$ and sodium hydroxide $(\mathrm{NaOH})$.

considerations, we designed a high-performance light responsive photocatalyst for antibiotic water remediation by doping Co onto $\mathrm{Ni}_{0.5} \mathrm{Zn}_{0.5} \mathrm{Fe}_{2} \mathrm{O}_{4}$ nanoparticles. Since cobalt is a hard magnetic material with larger atomic radii, it affects the oxygen position, the vacancy parameter, and the magneto-crystalline anisotropy constant (Debnath et al. 2021), charge transfer efficiency (Sinha 2021), and intrinsic coercivity of the pristine ferrite.

For the first time, a Co-doped $\mathrm{Ni}_{0.5} \mathrm{Zn}_{0.5} \mathrm{Fe}_{2} \mathrm{O}_{4}(\mathrm{Co}-\mathrm{NZF})$ photocatalyst was synthesized through two-step but simple protocols to decontaminate metronidazole antibiotic water and inactivate bacteria strains under UV irradiation. In the presence of other antibiotics or salts as interference, the photocatalytic activity of Co-NZF was investigated. Based on the experimental findings, active species trapping, and theoretical electronic structure estimation, the results obtained are remarkable, and a potential degradation mechanism is highlighted. Since it can degrade organics and inactivate bacterial strains, Co-NZF is expected to have a bright future in the water treatment industry, reducing human reliance on chlorine. It's also worth noting that, because of its magnetic properties, Co-NZF was easily and quickly isolated by an external magnet after repeated reuse cycles.
$125\left(\mathrm{Co}\left(\mathrm{NO}_{3}\right)_{2} \cdot 6 \mathrm{H}_{2} \mathrm{O}\right)$, Nickel (II) sulfate hexahydrate $\left(\mathrm{NiSO}_{4} \cdot 6 \mathrm{H}_{2} \mathrm{O}\right)$, hydrochloric acid $(\mathrm{HCl}, 37 \%)$, 126 Zinc (II) sulfate heptahydrate $\left(\mathrm{ZnSO}_{4} .7 \mathrm{H}_{2} \mathrm{O}\right)$, ethanol, Iron (III) chloride hexahydrate




\section{Synthesis of Co-doped $\mathrm{Ni}_{0.5} \mathrm{Zn}_{0.5} \mathrm{Fe}_{2} \mathrm{O}_{4}$}

130 To start, the co-precipitation method was used to synthesize $\mathrm{Ni}_{0.5} \mathrm{Zn}_{0.5} \mathrm{Fe}_{2} \mathrm{O}_{4}$ (NZF) nanoparticles 131 as shown in Scheme 1 (Mustafa and Oladipo, 2021). In $120 \mathrm{~mL}$ distilled water, $5.5 \mathrm{~g} \mathrm{ZnSO}$. $7 \mathrm{H}_{2} \mathrm{O}$, $1326 \mathrm{~g} \mathrm{NiSO}_{4} .6 \mathrm{H}_{2} \mathrm{O}$, and $5.7 \mathrm{~g} \mathrm{FeCl}_{3} .6 \mathrm{H}_{2} \mathrm{O}$ were dissolved. The solution was stirred at $250 \mathrm{rpm}$ 133 continuously until it became homogeneous, then $20 \mathrm{~mL}$ of $0.3 \mathrm{M}$ acetic acid was added to prevent 134 particle aggregation. The reaction flask was then transferred to an oil bath and vigorously stirred 135 at $800 \mathrm{rpm}$ for $180 \mathrm{~min}$ at $80^{\circ} \mathrm{C}$. The solution was cooled and dried overnight at $80^{\circ} \mathrm{C}$ before being 136 calcined in a muffle furnace for $120 \mathrm{~min}$ at $800^{\circ} \mathrm{C}$. $\mathrm{Ni}_{0.5} \mathrm{Zn}_{0.5} \mathrm{Fe}_{2} \mathrm{O}_{4}$ obtained was washed several 137 times with distilled water and dried. The chemical reaction for the formation of $\mathrm{Ni}_{0.5} \mathrm{Zn}_{0.5} \mathrm{Fe}_{2} \mathrm{O}_{4}$ is 138 shown as follows:

Co-precipitation stage:

$0.5 \mathrm{Ni}^{2+} 0.5 \mathrm{Zn}^{2+}+2.0 \mathrm{Fe}^{3+}+8 \mathrm{OH}^{-} \rightarrow 0.5 \mathrm{Ni}(\mathrm{OH})_{2} * 0.5 \mathrm{Zn}(\mathrm{OH})_{2} * 2.0 \mathrm{Fe}(\mathrm{OH})_{3} \downarrow$

Ferritization stage:

142

$0.5 \mathrm{Ni}(\mathrm{OH})_{2} * 0.5 \mathrm{Zn}(\mathrm{OH})_{2} * 2.0 \mathrm{Fe}(\mathrm{OH})_{3} \rightarrow \mathrm{Ni}_{0.5} \mathrm{Zn}_{0.5} \mathrm{Fe}_{2} \mathrm{O}_{4} \cdot n \mathrm{H}_{2} \mathrm{O}+(4-n) \mathrm{H}_{2} \mathrm{O}$ $\mathrm{M} \mathrm{Co}\left(\mathrm{NO}_{3}\right)_{2} \cdot 6 \mathrm{H}_{2} \mathrm{O}$; then stirred the solution at $250 \mathrm{rpm}$ at room temperature for $45 \mathrm{~min}$. The

145 reaction temperature was then raised to $70^{\circ} \mathrm{C}$, and $30 \mathrm{~mL}$ of $75 \mathrm{mM} \mathrm{NaOH}$ was added dropwise to 146 the mixture and stirred for another $60 \mathrm{~min}$. The precipitate was filtered, washed with water-50\% 147 ethanol mixture several times then dried at $100^{\circ} \mathrm{C}$ for $24 \mathrm{~h}$. The final product was ground and 148 sieved to a uniform size then labelled (Co-NZF). 


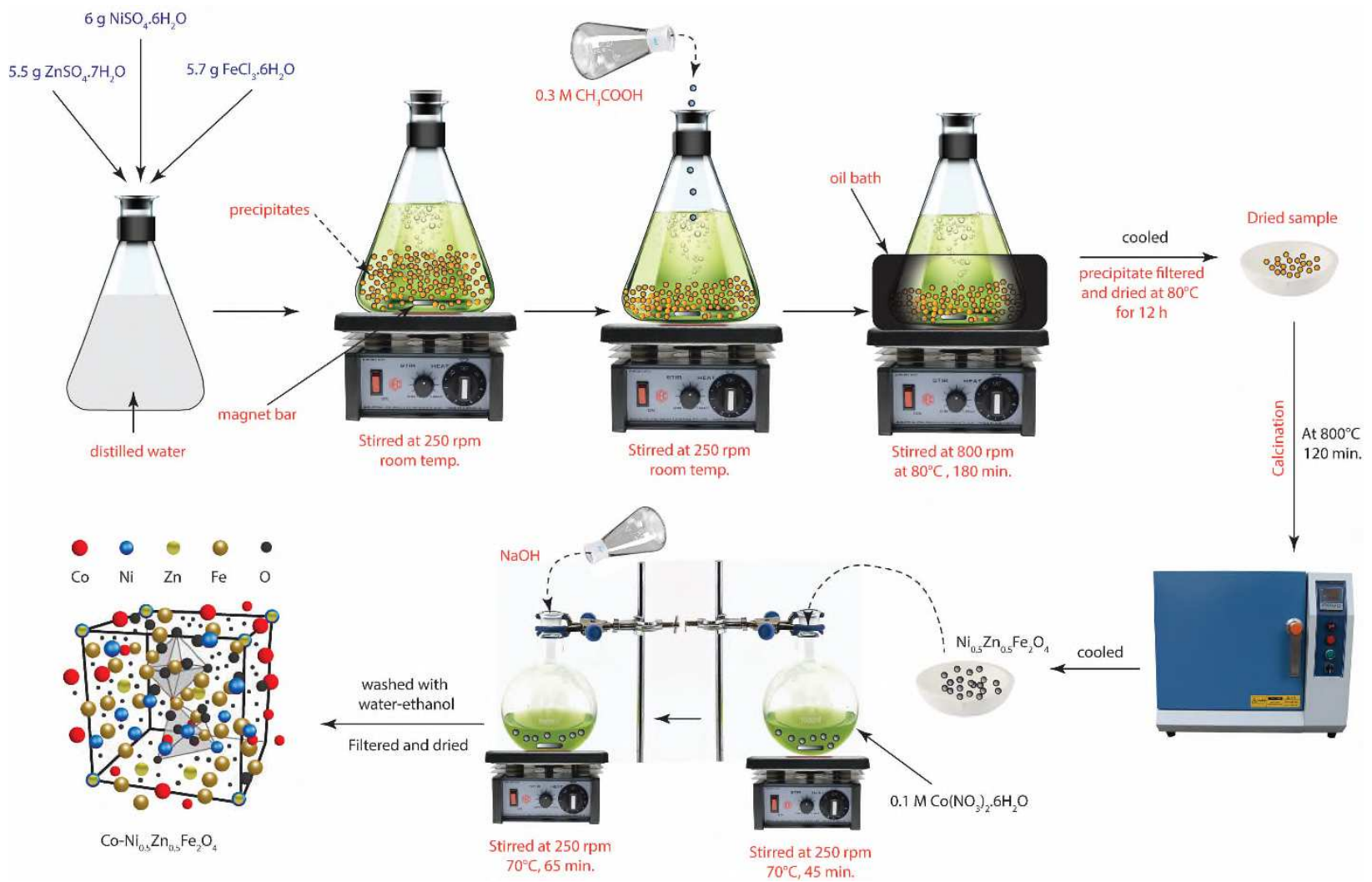

Scheme 1: Schematic illustration of the synthesis of $\mathrm{Co}-\mathrm{Ni}_{0.5} \mathrm{Zn}_{0.5} \mathrm{Fe}_{2} \mathrm{O}_{4}$

151

152

153

154

155

\section{Characterizations}

The Co-NZF was characterized by UV-vis diffuse reflectance spectroscopy (DRS) using a UV2450 spectrometer (Shimadzu, Japan) from $200 \mathrm{~nm}$ to $800 \mathrm{~nm}$. The SEM-EDX was acquired by JSM-6390 scanning electron microscope-coupled EDX (JEOL, Japan). The X-ray powder diffraction (XRD) patterns were recorded using X-ray diffractometer Bruker D8 (Bruker-AXS, Ettlingen, Germany) with a $\mathrm{Cu} \mathrm{K \alpha}(\lambda=1.54187 \AA)$ monochromatic radiation at $40 \mathrm{kV}$ and $30 \mathrm{~mA}$. The measurement was recorded at $2 \theta=5-70^{\circ}$ at a rate of $2^{\circ} \mathrm{min}^{-1}$ and the crystalline phases were clarified using standard JCPDS files. The electrochemical impedance spectroscopy (EIS) was investigated using the Palmsens Sensit smart potentiostat (PalmSens BV, Netherlands) in the frequency range of $50 \mathrm{~Hz}-200 \mathrm{kHz}$ at room temperature. Fourier Transform Infrared (FTIR) 
162 spectra were recorded in the range $4000-400 \mathrm{~cm}^{-1}$ using an FTIR-8700 spectrophotometer 163 (Perkin-Elmer, Japan). Photoluminescence spectrum (PL) was collected by fluorescence 164 spectrophotometer F-7000 (Hitachi High-Tech, Japan) with optical radiation at $\lambda=340 \mathrm{~nm}$. At 165 room temperature, a MicroSense Vibrating Sample Magnetometer (Model 10, MicroSense USA) 166 was used to investigate the magnetic properties of samples ranging within $\pm 10,000$ Oe.

\section{Photocatalytic degradation procedure}

A $200 \mathrm{mg} / \mathrm{L}$ stock solution of the metronidazole antibiotic was prepared by dissolving it in 171 deionized water. The stock solution was kept at $5^{\circ} \mathrm{C}$ until it was required. Diluting the stock

172 solution with a background solution yielded working solutions with concentrations ranging from 17310 to $100 \mathrm{mg} / \mathrm{L}$. The Co-NZF photocatalytic activity was investigated in a batch-type customized174 stirred pyrex-flask reactor under UV light (18 W, $385 \mathrm{~nm}$; T8W5, China).

176 dose was dispersed in $25 \mathrm{~mL}$ of $50 \mathrm{mg} \mathrm{L}^{-1} \mathrm{MZ}$ solution in the reactor, which was then stirred for $17730 \mathrm{~min}$ under darkness to achieve the adsorption/desorption state before UV light irradiation for $178360 \mathrm{~min}$. The initial $\mathrm{pH}$ values of the solutions were adjusted with $0.1 \mathrm{M} \mathrm{HCl} / \mathrm{NaOH}$. The Co179 NZF particles were separated from the solution using an external magnet periodically, and $2 \mathrm{~mL}$ 180 of the sample was taken and analyzed for residual MZ concentration using UV-vis spectroscopy 181 (T90+ UV-vis spectrophotometer PG Instruments Ltd, UK) at the $\lambda_{\max }=320 \mathrm{~nm}$ with a $1 \mathrm{~cm}$ path 182 length quartz cell. The concentrations were determined using a linear regression equation (y $183=0.0375 x+0.1967)$ derived from a calibration curve of $\mathrm{MZ}$ absorption plotted over a range of 184 concentrations with an $\mathrm{R}^{2}$ of 0.998 . The photocatalytic performance of $\mathrm{MZ}$ was examined by 185 varying parameters such as initial MZ concentration (10-100 mg/L), oxidant concentration 
$\left(\mathrm{H}_{2} \mathrm{O}_{2} / \mathrm{K}_{2} \mathrm{~S}_{2} \mathrm{O}_{4} ; 4-7 \mathrm{mM}\right)$ and dosage of Co-NZF (10-50 mg). To test the stability and reusability of Co-NZF, the spent photocatalyst was eluted with base-spiked distilled water, dried at $40^{\circ} \mathrm{C}$, and reused several times.

During the photocatalytic reaction, trapping experiments were carried out to investigate the contribution of radicals and active species. Before adding the Co-NZF, the MZ solution was spiked with $5 \mathrm{mM}$ 1,4-benzoquinone (BQ), tert-butyl alcohol ( $t$-BuOH), methanol and sodium oxalate $(\mathrm{NaOx})$ to scavenge ${ }^{\circ} \mathrm{O}_{2}{ }^{-},{ }^{\circ} \mathrm{OH},{ }^{\circ} \mathrm{SO}_{4}{ }^{-}$and $h^{+}$scavengers, respectively. The catalytic activity of Co-NZF was also studied when $50 \mathrm{mg} \mathrm{L}^{-1} \mathrm{MZ}$ interfered with antibiotics (1 $\mathrm{mg} \mathrm{L}^{-1}$ Tylosin and tetracycline) and various salts $\left(0.1 \mathrm{M}\right.$ of $\mathrm{NaCl}, \mathrm{KNO}_{3}$ and $\left.\mathrm{Na}_{2} \mathrm{SO}_{4}\right)$.

\section{Bacterial inactivation activities of $\mathrm{Co}-\mathrm{Ni}_{0.5} \mathrm{Zn}_{0.5} \mathrm{Fe}_{2} \mathrm{O}_{4}$ via time-kill assays}

Time-kill assays were used to investigate the antimicrobial efficacy of Co-NZF against Staphylococcus aureus (S. aureus, ATCC 2921) and Escherichia coli (E. coli, ATCC 25922) as shown in Scheme 2. In Muller Hinton Agar (MHA, Biomerieux, France) and MacConkey agar (MCA, Biomerieux, France), S. aureus and E. coli cultures were incubated overnight at $37^{\circ} \mathrm{C}$, respectively. Mueller Hinton Broth (MHB, Merck, Germany) was used to prepare the bacterial stock solutions, then standardized using 0.5 McFarland scale and diluted to $1 \times 10^{7} \mathrm{CFU} \mathrm{mL}^{-1}$ using sterile saline solution (0.85\%) as shown in Scheme 2. 5-25 mg of Co-NZF was mixed with the bacterial solutions and agitated at $200 \mathrm{rpm}$ either in the dark, or were exposed to the UV light $\left(\lambda_{\max }=365 \mathrm{~nm}\right)$ at a distance of $4 \mathrm{~cm}$. Flasks containing bacterial solutions that did not contain $\mathrm{Co}-$ NZF were used as a control group. Periodically, $10 \mathrm{~mL}$ of each sample was withdrawn and diluted with $90 \mathrm{~mL}$ of MHB. Finally, the diluted solutions were dropped onto the agar plate and incubated for $24 \mathrm{~h}$ at $37^{\circ} \mathrm{C}$. Following that, the colonies were counted, and the bacteria concentrations (CFU per $\mathrm{mL}$ ) and bacteria-killing efficacy (A\%) were calculated using Eqs. 4 and 5. 


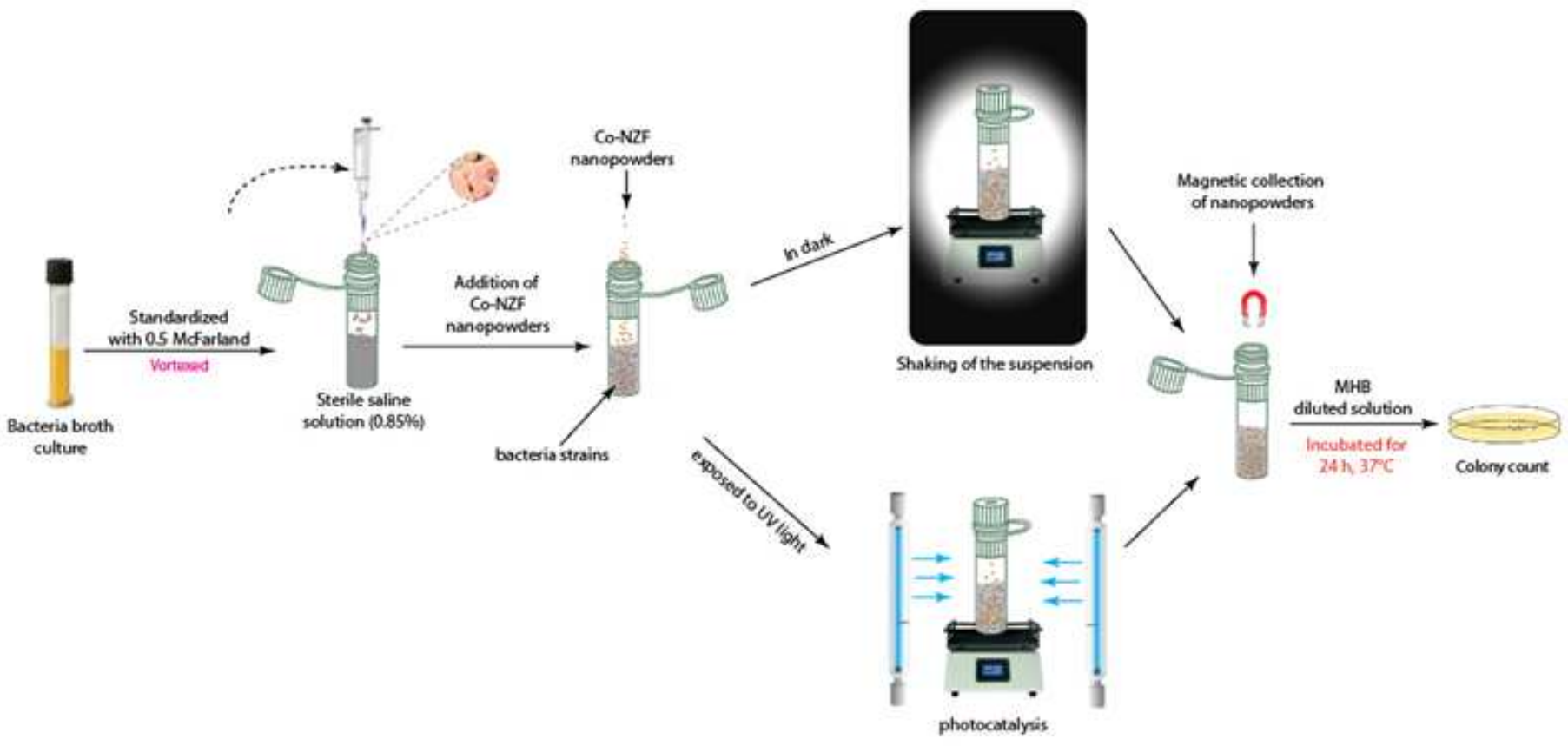

211 Scheme 2: Outline of the bacteria killing due to the catalytic reaction of $\mathrm{Co}-\mathrm{Ni}_{0.5} \mathrm{Zn}_{0.5} \mathrm{Fe}_{2} \mathrm{O}_{4}$

\section{Data analysis}

Each experiment was replicated twice, with an average outcome of $\pm 1.5 \%$ error. The photocatalytic

217 degradation efficiency, $\eta(\%)$, degradation kinetics and the electrical energy per order, $E_{E O}(\mathrm{kWh}$

$218 \mathrm{~m}^{-3}$ order $^{-1}$ ) required to decrease the concentration of MZ were calculated following Eqs. 1-3:

$219 \eta=\frac{1-C_{t}}{C_{0}} \times 100$

$220 \quad \ln \frac{C_{t}}{C_{o}}=-k_{o b s} t$

$221 E_{E O}=\frac{1000 P \times t}{V \times 60} \times \log \frac{C_{o}}{C_{t}}$ 
$222 \mathrm{CFUmL}^{-1}=\frac{\text { No.of colonies } \times \text { dilutionfactor }}{\text { Volume of culture plated }}$

$223 A(\%)=\frac{\text { No.of CFUs in control group }- \text { No.of CFU in exp.group }}{\text { No.of CFU(control group) }} \times 100$

224 where $C_{t}$ and $C_{o}(\mathrm{mg} / \mathrm{L})$ denote the $\mathrm{MZ}$ concentrations at time $t(\mathrm{~min})$ and before the reaction, 225 respectively; while $k\left(\min ^{-1}\right)$ is the apparent rate constant, $V(\mathrm{~L})$ denotes the reaction volume, $P$ is 226 the electrical power consumed during the process $(\mathrm{kW})$ and $t$ represents reaction time (min).

227 GraphPad Prism (ver.7, USA) was employed for data visualization.

228

229

Results and discussion

230 The NZF and Co-NZF FTIR spectra are shown in Fig. 1a. We used the abbreviations $v$ and $\delta$ to 231 denote stretching and bending vibrations, respectively, when interpreting infrared (IR) spectra.

232 Main assignments of IR wave-numbers are listed accordingly for NZF and Co-NZF;

233

NZF: $1145-983 \mathrm{~cm}^{-1} \delta(\mathrm{Fe}-\mathrm{O}-\mathrm{H} / \mathrm{M}=\mathrm{Ni}$ or $\mathrm{Zn}) ; 845-832 \mathrm{~cm}^{-1} v(\mathrm{Fe}-\mathrm{O}-\mathrm{M}) ; 578 \mathrm{~cm}^{-1} v(\mathrm{M}-$

$234 \mathrm{O} /$ metal-oxygen tetrahedral $(\mathrm{Fe} \leftrightarrow \mathrm{O})) ; 465 \mathrm{~cm}^{-1} v(\mathrm{M}-\mathrm{O} /$ octahedral $(\mathrm{Ni} \leftrightarrow \mathrm{O}$ and $\mathrm{Zn} \leftrightarrow \mathrm{O})) ; 415$

$235-600 \mathrm{~cm}^{-1}$ (characteristics bands of the spinel structure).

236 Co-NZF: $1153-1089 \mathrm{~cm}^{-1} \delta(\mathrm{Fe}-\mathrm{O}-\mathrm{H}) ; 476-469 \mathrm{~cm}^{-1} v(\mathrm{M}-\mathrm{O} / \mathrm{octahedral}$ and tetrahedral $(\mathrm{Ni}$ $237 \leftrightarrow \mathrm{O}$ and $\mathrm{Zn} \leftrightarrow \mathrm{O})$ ); $445 \mathrm{~cm}^{-1} v(\mathrm{Co}-\mathrm{O}) ; 415-600 \mathrm{~cm}^{-1}$ (characteristics bands of the spinel 238 structure).

239 As previously stated, the tetrahedral and octahedral sites are strongly preferred by $\mathrm{Zn}$ and $\mathrm{Ni}$ atoms, 240 respectively. $\mathrm{Fe}^{3+}$ cations, on the other hand, can occupy octahedral and tetrahedral sites (Thakur 241 et al. 2016; Debnath et al. 2021). According to Fig.1a, the changes of IR spectra of the doped 242 catalyst compared to the undoped catalyst can be outlined as follows. The $\mathrm{Fe}-\mathrm{O}-\mathrm{H}$ absorption 243 bands in Co-NZF deviated marginally to long-wave regions and decreased in intensity, which is 
244 likely due to the transformation of bond lengths or particle enlargement and crystal structure 245 perfection as a result of Co doping onto NZF (Sivaranjani et al.2019; Ivanovskaya et al. 2009).

246 Furthermore, in the $\mathrm{Co}-\mathrm{NZF}$ spectrum; the $\mathrm{Fe} \leftrightarrow \mathrm{O}$ tetrahedral and the octahedral bands $(\mathrm{Ni} \leftrightarrow \mathrm{O}$ 247 and $\mathrm{Zn} \leftrightarrow \mathrm{O}$ ) merged into a sharp peak centred at $473 \mathrm{~cm}^{-1}$. A new peak at $445 \mathrm{~cm}^{-1}$ was observed, 248 which was due to the stretching of the $\mathrm{Co}-\mathrm{O}$ and confirmed the existence of Co atoms in the $249 \mathrm{Ni}_{0.5} \mathrm{Zn}_{0.5} \mathrm{Fe}_{2} \mathrm{O}_{4}$ lattice. When the sample was sintered at $800^{\circ} \mathrm{C}$, the stretching vibrations induced 250 by the $\mathrm{C}-\mathrm{O}$ bond with peaks around $1091-1143 \mathrm{~cm}^{-1}$ were noticeably weakened which is similar 251 to the observation reported by Thakur et al. 2016.
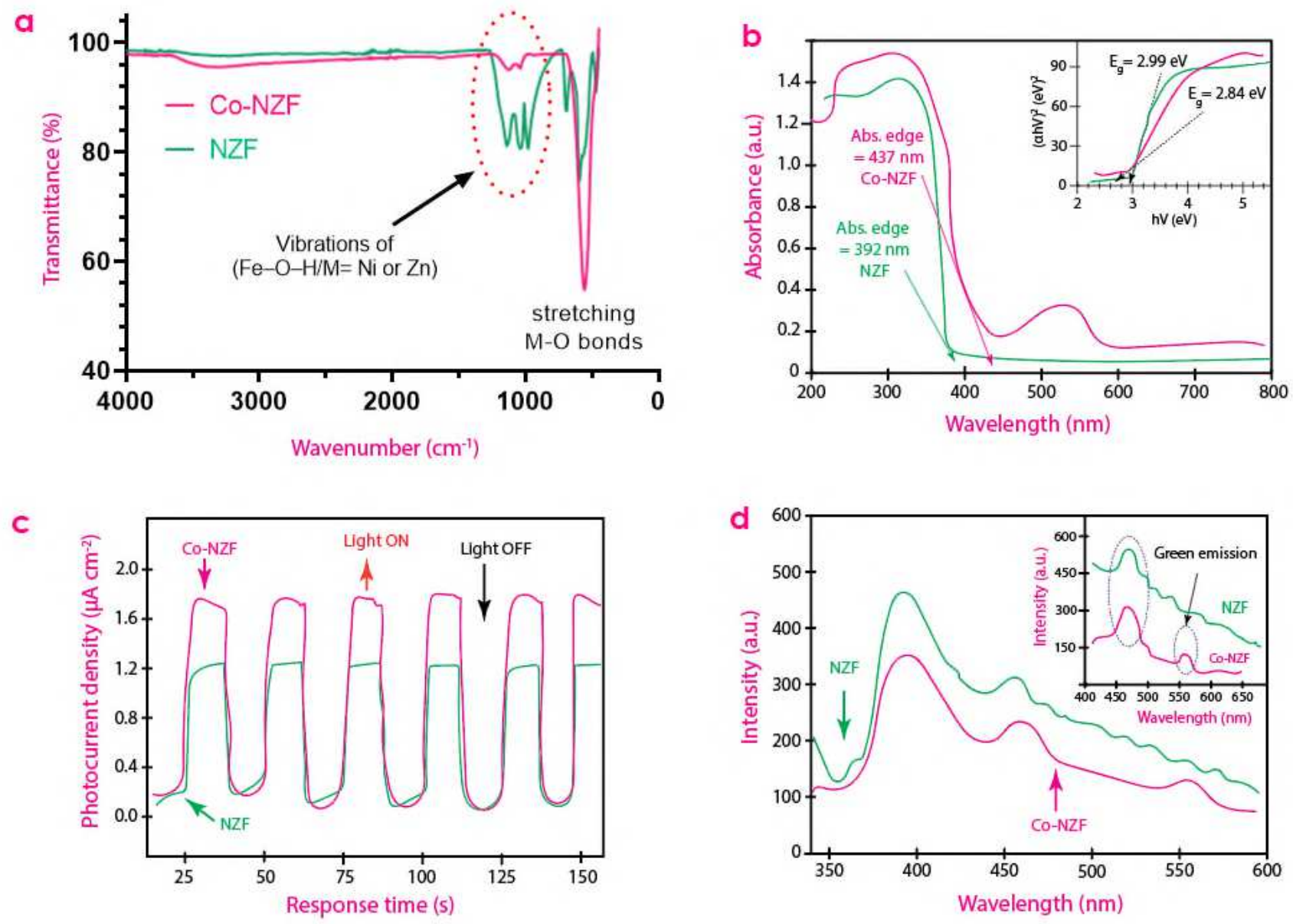

Fig.1: Characterization of NZF and Co-NZF (a) FTIR (b) UV-vis DRS (inset: band 255 energy gap from Tauc plots) (c) Transient photocurrent response (d) PL spectra. 

of 200-800 $\mathrm{nm}$ are represented in Fig.1b. Both samples have high absorption in the ultraviolet range; NZF, in particular, has an absorption in the UV region (345-396 $\mathrm{nm}$ ) due to intrinsic band transitions between the $\mathrm{M}^{+}$cations and $\mathrm{M}^{+}-\mathrm{O}_{2}{ }^{-}$, which is consistent with other studies (Qasim et al. 2015; Asadi and Moeinpour 2019; Aali et al. 2019; Nag et al., 2020). NZF has an absorption 261 edge at $392 \mathrm{~nm}$. The absorption edge of the $\mathrm{Co}-\mathrm{NZF}$ wavelength region extends into the visible 262 region $(437 \mathrm{~nm})$, with an absorption enhancement in the region of 450-595 $\mathrm{nm}$, which is due to 263 the interaction of the localized $d$-electrons of $\mathrm{Co}^{2+}$ and $s-$ and $p$-electron of the host NZF (Kaphle 264 et al. 2019). The absorption intensity of Co-NZF is greater than that of NZF in the $300-800 \mathrm{~nm}$ 265 range, implying that it may have better catalytic activity in the UV and visible regions. The optical 266 band gap $\left(\mathrm{E}_{g}\right)$ of the samples was calculated using Eq.6 (Oladipo et al.2019; Oladipo 2021ab) to 267 be $2.84 \mathrm{eV}$ and $2.99 \mathrm{eV}$ for $\mathrm{Co}-\mathrm{NZF}$ and NZF respectively.

$268 \quad E_{g}=\frac{1240}{\lambda_{\text {AbsorpEdge }}}$

269 Note that doping with Co ions generates oxygen vacancies, which promotes the formation of $\mathbf{M}^{x-1}$ 270 from $\mathrm{M}^{x}$ (host metal ions) (Chahal et al. 2020; Kaphle et al. 2019). This raises the number of $\mathbf{M}^{x-1}$ 271 states, resulting in the creation of localized energy states closer to the conduction band and thus 272 lowering the bandgap (Saranya et al. 2014).

Fig.1c displays the light response profiles of the NZF and $\mathrm{Co}-\mathrm{NZF}$ during multiple

274 irradiations of On/Off light. The photocurrent density increased rapidly when the irradiation light 275 was activated for both samples, then decreased to a constant value when the light was shut off. The 276 light response profiles of the NZF and $\mathrm{Co}-\mathrm{NZF}$ during multiple irradiations of On/Off light are 277 shown in Fig.1c. When the irradiation light was turned on for both samples, the photocurrent 
278 density increased rapidly but decreased to a constant value when the light was turned off. Co-NZF, 279 in particular, showed a photocurrent response of $1.73 \mathrm{~A} \mathrm{~cm}^{-2}$, which is 1.4 times higher than NZF. The photoluminescence (PL) technique was used to investigate the transfer and 281 recombination rate of the photogenerated charge carrier. Both samples had two emission bands 282 about $360-485 \mathrm{~nm}$, as shown in Fig.1d. The broad $389 \mathrm{~nm}$ emission originates from an exciton283 exciton collision mechanism from the recombination of the free excitons and is typically referred 284 to as UV band edge emission (Ahmad et al. 2020). At $468 \mathrm{~nm}$, the broad blue-green emission band 285 is possibly due to the direct recombination of electrons in CB and holes in VB and oxygen defects 286 (Saranya et al. 2014). On doping NZF with Co, the emission peaks redshifted and more oxygen 287 defects were formed which resulted in a weak green emission band observed at $\sim 559 \mathrm{~nm}$. In 288 contrast to NZF, Co-NZF had a lower PL intensity; note that the lower the PL intensity, the lower 289 the $e^{-}$and $h^{+}$recombination rate.

SEM micrographs of NZF and Co-NZF are shown in Fig.2a. When examined closely, 291 the Co-NZF has a spongy morphology with agglomerated irregular grain shapes which is 292 consistent with the SEM of Ni-Zn ferrite reported by Džunuzović et al 2015. The crystallites' 293 dipole interactions might have caused the agglomeration. The crystals are not completely 294 monodisperse, and the average particle size of the samples is found to be between 23 and $28 \mathrm{~nm}$. 295 In both samples, several grain surfaces have hexagonal shapes and distorted edges, which is the 296 basic crystal cell unit of ferrites (Thakur et al. 2016; Mustafa and Oladipo 2021). The presence of 297 metal ions with compositions consistent with the predicted stoichiometry of $\mathrm{Ni}_{0.5} \mathrm{Zn}_{0.5} \mathrm{Fe}_{2} \mathrm{O}_{4}$ was 298 verified by energy-dispersive X-ray spectroscopy (EDX) analysis of the samples (Fig.2b). It's 299 worth noting that the Pd and Au peaks in the spectra correspond to the metallic coater used in the 300 experiments. 
Fig.2c depicts the magnetic hysteresis loop for NZF and Co-NZF samples at room

302

303

304

305

306

307

308

309

310

311

312

temperature. The magnetization results revealed ferromagnetic activity which is common for soft magnetic material (Džunuzović et al 2015). NZF's saturation magnetization $\left(\mathrm{M}_{\mathrm{s}}\right)$ is $79.28 \mathrm{emu}^{-1}$, which is less than $\mathrm{Co}^{-} \mathrm{NZF}^{\prime} \mathrm{s}\left(85.94 \mathrm{emu} \mathrm{g}^{-1}\right)$; while these values are higher than the 57-78 emu $\mathrm{g}^{-1}$ stated previously (Džunuzović et al 2015; Thakur et al. 2016). Because of the Co doping, $\mathrm{Co}-\mathrm{NZF}$ has a higher crystallinity and saturation magnetization moment than NZF. The Co which is magnetic caused $\mathrm{Fe}^{3+}$ ions to migrate from tetrahedral to octahedral sites, disrupting ion equilibrium and increasing magnetization. Co doping, on the other hand, resulted in a slight increase in grain size in $\mathrm{Co}-\mathrm{NZF}$, with a lower coercivity $\left(\mathrm{H}_{\mathrm{c}}\right)$ of 57.94 Oe than NZF (61.21 Oe). The $\mathrm{M}_{\mathrm{r}} / \mathrm{M}_{s}$ varies from 0.935 to 0.969 for both samples, which is closer to the average value of 1 for single-domain ferromagnetic particles. An external magnet can easily extract $\mathrm{Co}-\mathrm{NZF}$ from aqueous solutions due to its high magnetic properties.

The electrochemical properties of the samples were investigated using impedance spectroscopy. Semicircular arcs were observed in both NZF and $\mathrm{Co}-\mathrm{NZF}$ due to grain boundary conduction at low frequencies and high frequencies. The radius of the arc represents the interfacial charge transfer resistance $\left(\mathrm{R}_{c t}\right)$ in the EIS Nyquist plots in Fig.2d. Co doping resulted in increased defects (vacancies), which led to a decrease in $\mathrm{Co}^{-} \mathrm{NZF}$ 's resistance, as predicted by the PL study. The decrease in resistivity can also be due to the reduction in the number of grain boundaries caused by the increase in grain size in the Co-NZF (Džunuzović et al 2015; Mustafa and Oladipo 2021). The $\mathrm{Co}^{-} \mathrm{NZF}$ has a lower $\mathrm{R}_{c t}$ value, indicating that it has a higher charge transfer efficiency than NZF. Under UV irradiation, Co-NZF had the smallest semi-circle diameter and a significantly lower $\mathrm{R}_{c t}$ value than $\mathrm{NZF}$, implying a greater separation of photogenerated electron- 
323 hole pairs and transfer efficiency, resulting in the highest photocatalytic activity against MZ 324 degradation.
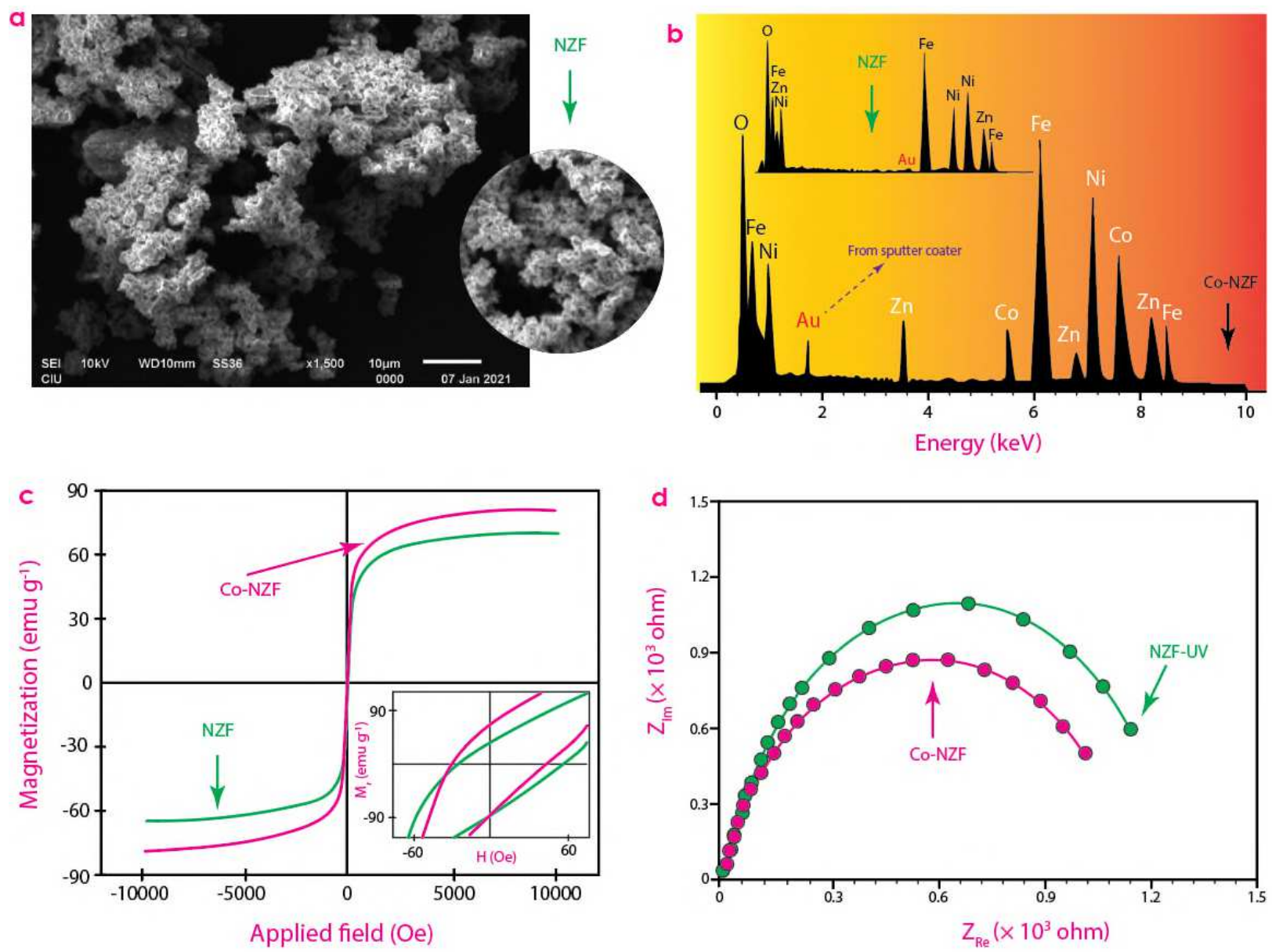

Fig.2: (a) SEM images (b) EDX spectra (c) magnetic parameters and (d) EIS Nyquist plots of 329

the standard pattern of the cubic spinel structure of $\mathrm{Ni}_{0.5} \mathrm{Zn}_{0.5} \mathrm{Fe}_{2} \mathrm{O}_{4}$ ferrite (JCPDS\# 52-0278,

332 JCPDS\# 10-0325 and JCPDS\# 08-0234) at the position of $2 \theta=18.36^{\circ}, 30.14^{\circ}, 35.58^{\circ}, 37.11^{\circ}$,

$33343.18^{\circ}, 51.94^{\circ}, 57.18^{\circ}, 62.88^{\circ}, 71.5^{\circ}$ and $75.14^{\circ}$ matching $(111),(220),(311),(222),(400),(422)$, 
334 (511), (440), (620) and (533) Miller indices (Qasim et al. 2015; Džunuzović et al 2015; Thakur et

335 (220), (311) and (440) as 19.9 and $25.6 \mathrm{~nm}$, respectively.

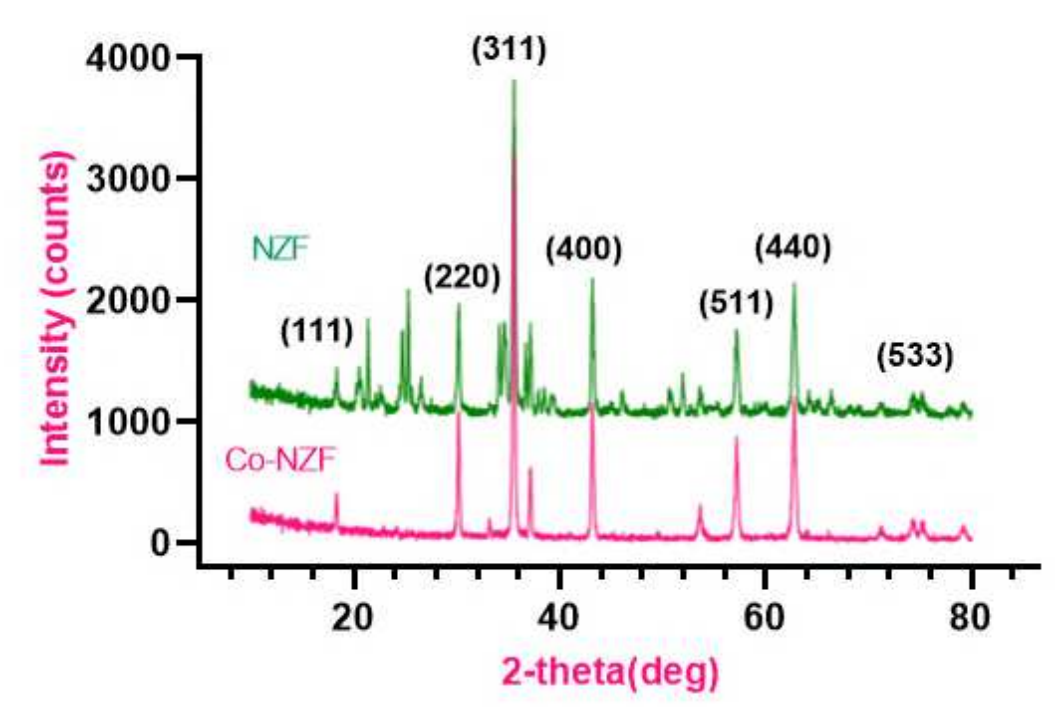

345 decreased dislocation density and increased average lattice constant (Table 1) due to the

al. 2016; Nag et al. 2020).

Similar diffraction peaks were observed in $\mathrm{Co}-\mathrm{NZF}$. As a result, cobalt $\left(\mathrm{Co}^{2+}\right)$ ion doping in NZF ferrite does not affect the NZF spinel phase because cobalt occupies interstitial space in the ferrite's cubic structure. However, other unidentified peaks between $21.14^{\circ}-27.5^{\circ}$ disappeared and there was a minor change towards the lower angle in the $2 \theta$ position for each peak, which may be due to the replacement of $\mathrm{Fe}^{3+}$ having ionic radii of $0.65 \AA$ by $\mathrm{Co}^{2+}$ with higher ionic radii of $\sim 0.74 \AA$ (Debnath et al. 2021; Sinha 2021). According to the Debye Scherrer equation $(\mathrm{D}=0.9 \lambda / \beta$ $\cos \theta$ ), the average crystallite size of NZF and $\mathrm{Co}-\mathrm{NZF}$ was estimated from the intense peaks

$$
\text { (220), (311) and (440) as } 19.9 \text { and } 25.6 \mathrm{~nm} \text {, respectively. }
$$

Fig.3: XRD patterns of the $\mathrm{Co}-\mathrm{NZF}$ and NZF 
350 radii ( 0.74 $\AA$ ) (Debnath et al. 2021; Mustafa and Oladipo 2021). In addition, the strain has been

351 induced in the system as a result of lattice expansion, and the positive sign indicates tensile stress

352 (Chahal et al. 2020). Table 1 lists the textural characteristics of Co-NZF and NZF. According to

353 the findings, both samples have meso and micropores. However, the mesopore volume of Co-NZF

354 is $~ 1.4$ times larger than that of NZF and its specific surface area is slightly lower which is likely

355 due to $(i)$ the aggregation of small cobalt particles into larger bulk particles of Co during the doping

356 process (ii) owing to the doping of $\mathrm{Co}^{2+}$ (which is magnetic) onto NZF, the $\mathrm{Co}-\mathrm{NZF}$ has a higher

357 magnetization saturation than the NZF, which further enhances its agglomeration. Ali et al. (2016)

358 also found that doping Ag onto a FeAlO sample reduced its surface area. Also, the specific surface

359 areas of NZF and Co-NZF were determined as $56.2 \mathrm{~m}^{2} \mathrm{~g}^{-1}$ and $44.0 \mathrm{~m}^{2} \mathrm{~g}^{-1}$ respectively based on

360 crystallite size. Since most of the grain boundaries in the crystallite are not accessible, these values

361 are significantly lower than those obtained using the BET. Since the particle size increased with

362 Co doping, the surface area of $\mathrm{Co}-\mathrm{NZF}$ is less than that of NZF, which is consistent with the BET

363 results.

365 Table 1: Surface and crystal characteristics of NZF and $\mathrm{Co}-\mathrm{NZF}$

\begin{tabular}{|c|c|c|c|}
\hline Parameters & Notes & a NZF & Co-NZF \\
\hline \multicolumn{4}{|c|}{ Surface area and pore volume } \\
\hline $\mathrm{S}_{\mathrm{BET}}\left(\mathrm{m}^{2} \mathrm{~g}^{-1}\right)$ & $\begin{array}{l}\text { Brunauer-Emmett-Teller specific surface area } \\
\text { obtained via } \mathrm{N}_{2} \text { adsorp. isotherm at } \mathrm{P} / \mathrm{Po}=0.05- \\
0.35 \text {. }\end{array}$ & 73.5 & 70.2 \\
\hline $\mathrm{V}_{\mathrm{t}}\left(\mathrm{cm}^{3} \mathrm{~g}^{-1}\right)$ & Total pore volume measured at $\mathrm{P} / \mathrm{Po} \sim 0.99$ & 0.287 & 0.298 \\
\hline $\mathrm{V}_{\text {mic }}\left(\mathrm{cm}^{3} \mathrm{~g}^{-1}\right)$ & Micropore pore volume. & 0.158 & 0.117 \\
\hline $\mathrm{V}_{\text {mes }}\left(\mathrm{cm}^{3} \mathrm{~g}^{-1}\right)$ & $\begin{array}{l}\text { Mesopore volume obtained by deducting } \mathrm{V}_{\text {mic }} \text { from } \\
\mathrm{V}_{\mathrm{t}} \text {. }\end{array}$ & 0.129 & 0.181 \\
\hline \multicolumn{4}{|c|}{ XRD structural data } \\
\hline $\mathrm{D}(\mathrm{nm})$ & $\begin{array}{l}\text { Average crystallite size calculated through Debye } \\
\text { Scherer's formula }=k \lambda / \beta \cos \theta, \mathrm{k}=0.94 ; \beta= \\
\text { FWHM. }\end{array}$ & 19.9 & 25.6 \\
\hline$\delta \times 10^{-3}\left(\mathrm{~nm}^{-2}\right)$ & Dislocation density calculated from $\delta=1 / \mathrm{D}^{2}$ & 2.52 & 1.52 \\
\hline
\end{tabular}




$$
\begin{aligned}
& \varepsilon \times 10^{-3}\left(\mathrm{~nm}^{-2}\right) \\
& \mathrm{X}(\%) \\
& \mathrm{a}(\mathrm{nm}) \\
& \mathrm{d}(\mathrm{nm}) \\
& \mathrm{V}\left(\mathrm{nm}^{3}\right) \\
& \rho\left(\mathrm{g} \mathrm{cm}^{-3}\right) \\
& \mathrm{S}\left(\mathrm{m}^{2} \mathrm{~g}^{-1}\right)
\end{aligned}
$$$$
\text { Lattice strain }=\beta / 4 \tan \theta
$$

$\%$ Crystallinity $=\mathrm{I}_{\text {crystal. peaks }} /\left(\mathrm{I}_{\text {crystal. peaks }}+\mathrm{I}_{\text {amorph. peaks }}\right)$.

66.8

\begin{tabular}{lccccccccc}
\hline & \multicolumn{1}{c}{ Magnetic parameters } & \multicolumn{1}{c}{ EDX parameters Wt. (\%) } \\
\hline Samples & $\mathrm{M}_{s}$ & $\mathrm{M}_{r}$ & $\mathrm{H}_{c}$ & $\mathrm{M}_{\mathrm{r}} / \mathrm{M}_{s}$ & $\mathrm{Co}$ & $\mathrm{Fe}$ & $\mathrm{Ni}$ & $\mathrm{Zn}$ & $\mathrm{O}$ \\
& $\left(\mathrm{emu} \mathrm{g}^{-1}\right)$ & $\left(\mathrm{emu} \mathrm{g}^{-1}\right)$ & $(\mathrm{Oe})$ & & & & & & \\
& 85.94 & 80.35 & 57.94 & 0.935 & 7.2 & 49.7 & 12.9 & 13.3 & 16.9 \\
$\mathbf{C o}-\mathbf{N Z F}$ & 79.28 & 76.81 & 61.21 & 0.969 & 0 & 51.3 & 13.7 & 15.6 & 19.4 \\
\hline
\end{tabular}

a Mustafa and Oladipo 2021

\section{Evaluation of Co-NZF under varying experimental conditions}

Note that NZF's performance is noticeably lower than Co-NZF's, which was achieved at a longer reaction time in a series of tests. As a consequence, only $\mathrm{Co}^{-} \mathrm{NZF}$ findings are presented in this article.

\section{Effect of $\mathrm{pH}$ variation}

When the $\mathrm{pH}$ of $50 \mathrm{mgL}^{-1} \mathrm{MZ}$ solution was varied in the absence and presence of oxidants (4 mM $\mathrm{H}_{2} \mathrm{O}_{2}$ or $5 \mathrm{mM} \mathrm{K}_{2} \mathrm{~S}_{2} \mathrm{O}_{8}$ ) at $200 \mathrm{rpm}$, a preliminary test was performed to evaluate the photocatalytic degradation of $\mathrm{MZ}$ using $25 \mathrm{mg} \mathrm{Co}-\mathrm{NZF}$. The $\mathrm{pH}$-dependent speciation of $\mathrm{MZ}(\mathrm{p} K a=2.5)$ and the surface chemistry of $\mathrm{Co}-\mathrm{NZF}\left(\mathrm{pH}_{\mathrm{pzc}}=6.69\right.$; Fig.4a) are used to explain the $\mathrm{MZ}$ degradation behaviour here. The Co-NZF degradation efficiency reached a maximum of $74.9 \%$ without an oxidant at $\mathrm{pH} 3$ then decreased steadily with increasing $\mathrm{pH}$. MZ degradation reached $93.4 \%$ at $\mathrm{pH}$ 3 in the presence of $\mathrm{H}_{2} \mathrm{O}_{2}$ and $\mathrm{Co}-\mathrm{NZF}$, while when the solution $\mathrm{pH}$ was increased beyond $\mathrm{pH} 3$, MZ degradation decreased remarkably and reached $16.3 \%$ at $\mathrm{pH}$ 9. In the $\mathrm{K}_{2} \mathrm{~S}_{2} \mathrm{O}_{8} / \mathrm{Co}^{-} \mathrm{NZF}$ system, 
maximum degradation was observed at $\mathrm{pH} 3$ which decreased to $32.6 \%$ at $\mathrm{pH} 9$ (Fig.4b). Except

388 in the presence of $\mathrm{K}_{2} \mathrm{~S}_{2} \mathrm{O}_{8}$, the $\mathrm{pH}$ of the final solutions increased before remaining marginally 389 stable at $\mathrm{pH} 6.87$.

390 The following is an interpretation of the removal behaviour as a function of $\mathrm{pH}$ variation:

391 the anionic $\mathrm{MZ}^{-}$, which are electron-deficient species, are dominant in the solution at $\mathrm{pH} 3$ due to 392 its $\mathrm{pKa}$ and are electrostatically attracted to the positively charged $\mathrm{Co}-\mathrm{NZF}^{+}$(since the $\mathrm{pH}$ is less 393 than the $\left.\mathrm{pH}_{\mathrm{pzc}}=6.69\right)$, resulting in higher degradation efficiency (Fakhravar et al. 2020). The 394 higher degradation of $\mathrm{MZ}$ at acidic $\mathrm{pH}$ compared to that at $\mathrm{pH} 6$ may likely be attributed to the 395 hydrolysis of MZ (Azalok et al. 2021b). The formation of ${ }^{\circ} \mathrm{OH}$ radicals, which can boost the 396 reaction rate and photocatalytic efficiency of the $\mathrm{Co}-\mathrm{NZF}$, is responsible for the higher 397 degradation observed in the presence of $\mathrm{H}_{2} \mathrm{O}_{2}$. $\mathrm{MZ}$ adsorption on the surface of $\mathrm{Co}^{-\mathrm{NZF}}$ (during 398 photocatalytic degradation) can occur through a combination of processes such as electrostatic 399 attraction, hydrogen bonding, and complex formation between $\mathrm{MZ} \pi$-electrons and the $\mathrm{Co}-\mathrm{NZF}$ 400 metal ions between $\mathrm{pH} 3$ and 7. At pH 9, lower degradation efficiency occurred due to repulsion 401 between the negatively charged $\mathrm{MZ}^{-}$, hydroxyl ions and the negatively charged $\mathrm{Co}^{-} \mathrm{NZF}^{-}$. Other 402 researchers have identified similar photodegradation activities for MNZ (Farzadkia et al. 2015; 403 Bashiri et al. 2020); hence, subsequent studies were conducted at $\mathrm{pH} 3$. 
$\mathbf{a}$
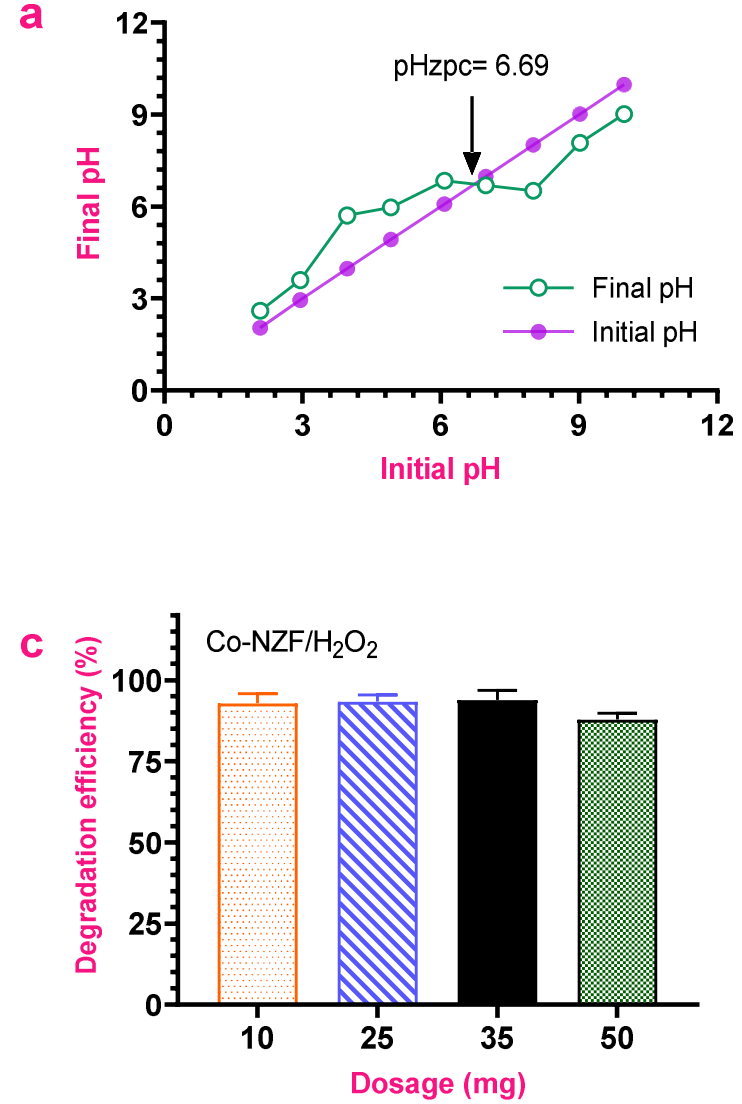
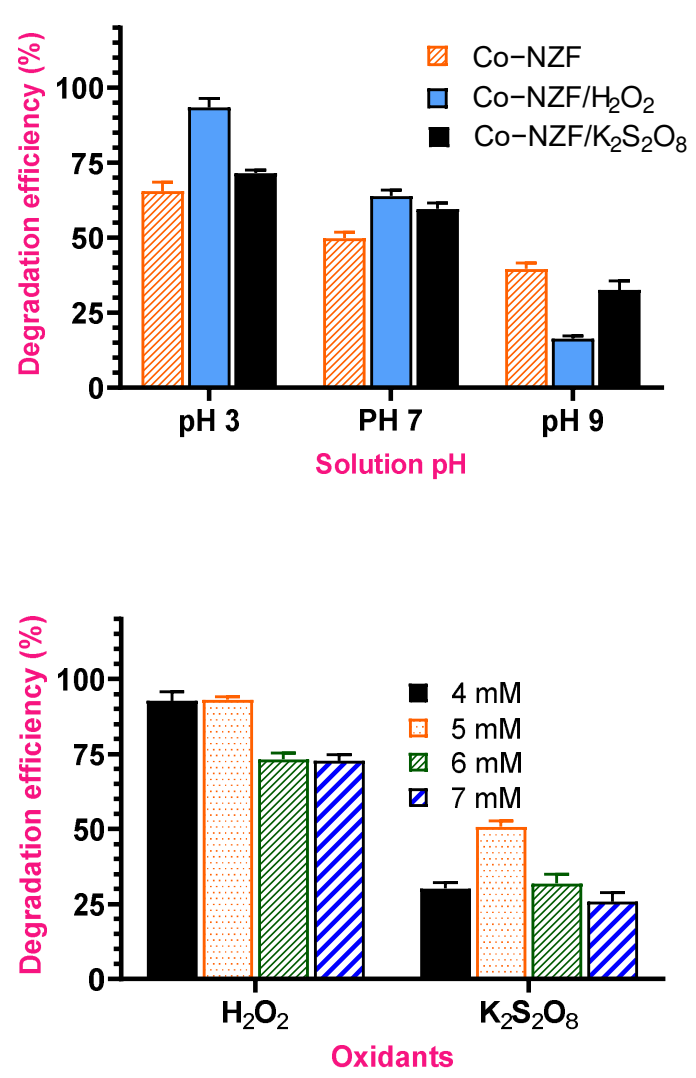

404

405

406

407

408

409

410

411

412

413

414

415

416

417

Fig.4: (a) $\mathrm{pH}$ point zero charge determination, and variation in (b) solution $\mathrm{pH}$ (c) $\mathrm{Co}-\mathrm{NZF}$ dosage (d) oxidant concentration. Reaction conditions: reaction time $=360 \mathrm{~min}$; initial $\mathrm{MZ}$ conc. $=$ $50 \mathrm{mgL}^{-1}$ and $\mathrm{MZ}$ vol. $=25 \mathrm{~mL}$.

\section{Variation in Co-NZF dosage and oxidant concentration}

The degradation efficiency of $50 \mathrm{mgL}^{-1} \mathrm{MZ}$ and the final concentration as the dose of Co-NZF was varied at $\mathrm{pH} 3$ in the presence of $4 \mathrm{mM} \mathrm{H}_{2} \mathrm{O}_{2}$ are shown in Fig.4c. When the Co-NZF dosage

was increased from $10 \mathrm{mg}$ to $35 \mathrm{mg}$, the degradation efficiency increased marginally from $92.8 \%$ to $93.9 \%$. When the $\mathrm{Co}-\mathrm{NZF}$ dose was increased to $50 \mathrm{mg}$, the degradation efficiency decreased slightly to $87.7 \%$. The observed decreasing trend in degradation efficiency when the $\mathrm{Co}-\mathrm{NZF}$ dosage reached $50 \mathrm{mg}$ is most likely due to one of three factors: $(i)$ increased suspension turbidity due to increased catalyst in the bulk, which resulted in decreased UV light penetration and 
419 photoactivation efficiency (Sathya et al. 2017; Bajorek et al. 2019; Oladipo 2021ab); (ii) the 420 aggregation of excess Co-NZF might decrease its effective surface area and adsorption of the MZ 421 species (Aram et al. 2020) or (iii) as the amount of catalyst in the suspension increased, photon422 activated $\mathrm{Co}-\mathrm{NZF}$ species were deactivated by collision with excess $\mathrm{Co}-\mathrm{NZF}$, as shown in Eq. 7.

423

424

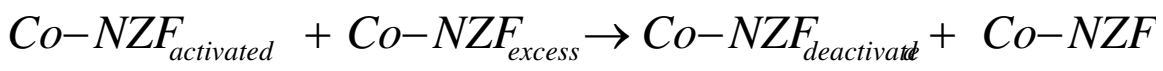

425

Arghavan et al. 2021 reported a similar phenomenon when they used a nickel ferrite-

426 based nanocomposite to degrade metronidazole under simulated sunlight irradiation. They 427 observed an increase in activity from 0.005 to $0.04 \mathrm{gL}^{-1}$ in catalyst dose, then a decrease at higher 428 catalyst loadings. In this study, further experiments were carried out using $10 \mathrm{mg}$ of $\mathrm{Co}-\mathrm{NZF}$ per $42925 \mathrm{~mL}$ of $\mathrm{MZ}$ because there were no major variations in $\mathrm{Co}-\mathrm{NZF}$ performance when $10 \mathrm{mg}$ and $430 \quad 35 \mathrm{mg}$ were used.

When the oxidants' initial concentrations were varied from $4 \mathrm{mM}$ to $7 \mathrm{mM}$, the $\mathrm{MZ}$ 432 degradation efficiency is shown in Fig.4d. When $\mathrm{H}_{2} \mathrm{O}_{2}$ concentration was increased from $4 \mathrm{mM}$ to $4336 \mathrm{mM}$, MZ degradation efficiency decreased from $92.8 \%$ to $73.3 \%$, then remained nearly 434 unchanged when $7 \mathrm{mM} \mathrm{H}_{2} \mathrm{O}_{2}$ was used. The decreasing trend is most likely due to an excess of $435 \mathrm{H}_{2} \mathrm{O}_{2}$ in the system scavenging the produced ${ }^{\circ} \mathrm{OH}$ radicals, potentially resulting in less reactive 436 hydroperoxyl radicals ( $\left.{ }^{\circ} \mathrm{OOH}\right)$ (Azalok et al. 2021ab). Based on the findings, a concentration of 4 $437 \mathrm{mM}$ of $\mathrm{H}_{2} \mathrm{O}_{2}$ was chosen for subsequent experiments.

438 When the concentration of $\mathrm{K}_{2} \mathrm{~S}_{2} \mathrm{O}_{8}$ was increased from $4 \mathrm{mM}$ to $5 \mathrm{mM}$, MZ degradation 439 increased from $30.2 \%$ to $50.8 \%$. Increased $\mathrm{K}_{2} \mathrm{~S}_{2} \mathrm{O}_{8}$ concentration resulted in more oxidative 440 radicals $\left({ }^{\circ} \mathrm{SO}_{4}{ }^{-}\right.$and ${ }^{\circ} \mathrm{OH}$ ), which favoured $\mathrm{MZ}$ degradation. However, the degradation efficiency 441 decreased to $25.8 \%$ when $\mathrm{K}_{2} \mathrm{~S}_{2} \mathrm{O}_{8}$ concentration was elevated to $7 \mathrm{mM}$. This is likely due to the 
442 competitive consumption of the free ${ }^{\circ} \mathrm{SO}_{4}{ }^{-}$radicals by the excess $\mathrm{K}_{2} \mathrm{~S}_{2} \mathrm{O}_{8}$ or generation of 443 comparatively weaker ${ }^{\circ} \mathrm{SO}_{5}{ }^{-}(1.1 \mathrm{eV})($ Chen et al. 2018); hence, the rate of degradation reduced.

444 Subsequent studies were carried out using $5 \mathrm{mM} \mathrm{K}_{2} \mathrm{~S}_{2} \mathrm{O}_{8}$.

445

446

\section{Variation in initial MZ concentration}

447 The photocatalytic degradation efficiencies of MZ when the concentration was varied from 10 to $448100 \mathrm{mgL}^{-1}$ in the presence of $10 \mathrm{mg} \mathrm{Co}-\mathrm{NZF} / 4 \mathrm{mM} \mathrm{H}_{2} \mathrm{O}_{2}$ per $25 \mathrm{~mL}$ of $\mathrm{MZ}$ at $\mathrm{pH} 3$ are shown in 449 Fig.5a. The degradation efficiency shows an increasing pattern as the initial concentration of MZ

450

451

452

453

454

455

456

457

458

459

460

461

462

463

464 was increased from 10 to $50 \mathrm{mgL}^{-1}$, and then dramatically decreased. The degradation efficiency reached $92.8 \%$ after a $6 \mathrm{~h}$ reaction with a $50 \mathrm{mgL}^{-1} \mathrm{MZ}$ concentration; however when the $\mathrm{MZ}$ concentration was increased to $100 \mathrm{mgL}^{-1}$, it decreased to $52.3 \%$. The lower degradation efficiency observed at $100 \mathrm{mgL}^{-1}$ of $\mathrm{MZ}$ is due to an insufficient number of reaction sites or active radicals to satisfy the increasing $\mathrm{MZ}$ species, as the $\mathrm{Co}-\mathrm{NZF}$ dosage remained constant.

The MZ degradation was investigated under optimized conditions. In preliminary adsorption experiments conducted in the dark for $12 \mathrm{~h}$ using $10 \mathrm{mg} \mathrm{Co}-\mathrm{NZF}, 70.2 \% \mathrm{MZ}$ adsorption was observed while MZ self-degradation was significantly negligible in a blank experiment (without $\mathrm{Co}-\mathrm{NZF}$ in the dark). As shown in Fig.5b, without the catalyst, $5.86 \%$ of MZ was photolytically degraded (under UV irradiation alone), but when $4 \mathrm{mM} \mathrm{H}_{2} \mathrm{O}_{2}$ and $5 \mathrm{mM} \mathrm{K}_{2} \mathrm{~S}_{2} \mathrm{O}_{8}$ were added within $360 \mathrm{~min}$, the degradation increased to $33.9 \%$ and $44.8 \%$, respectively. After 6 $\mathrm{h}$ of UV irradiation in the presence of $10 \mathrm{mg} \mathrm{Co}-\mathrm{NZF}$ and no oxidant, the $\mathrm{MZ}$ degradation efficiency reached a peak of $68.6 \%$. Even though the degradation efficiency in the dark is higher than under UV, the UV synergistically stimulated $\mathrm{Co}-\mathrm{NZF}$, causing it to generate photoinduced charge carriers and aided the degradation rate as compared to when it was dark. 

and $50.8 \%$ degradation, respectively. However, according to the kinetic studies shown in Fig.5c,

467 the $\mathrm{Co}-\mathrm{NZF} / \mathrm{H}_{2} \mathrm{O}_{2} / \mathrm{UV}$ system had a faster degradation rate and reached the maximum before $6 \mathrm{~h}$. 468 When compared to photolysis (UV alone), $\mathrm{H}_{2} \mathrm{O}_{2} / \mathrm{UV}$ and $\mathrm{K}_{2} \mathrm{~S}_{2} \mathrm{O}_{8} / \mathrm{UV}$ systems, the 469 photodegradation activity of $\mathrm{Co}-\mathrm{NZF} / \mathrm{H}_{2} \mathrm{O}_{2} / \mathrm{UV}$ increased remarkably by $15.8,2.74$ and 1.74 470 times, respectively. The increased performance is attributed to Co-NZF's activation of $\mathrm{H}_{2} \mathrm{O}_{2}$ that 471 generated ${ }^{\circ} \mathrm{OH}$ radicals to enhance the degradation of $\mathrm{MZ}$ as represented in Eqs. 8-10.

$472 \mathrm{Co}-\mathrm{NZF}\left(\mathrm{E}_{\mathrm{g}}=2.84 \mathrm{eV}\right) \stackrel{\text { UVlight }}{\longrightarrow} \mathrm{h}_{\mathrm{Vb}}^{+}+\mathrm{e}_{\mathrm{Cb}}^{-}$

$473 \quad \mathrm{e}_{\mathrm{Cb}}^{-}+\mathrm{H}_{2} \mathrm{O}_{2} \rightarrow{ }^{\bullet} \mathrm{OH}+\mathrm{OH}^{-}$

$474 \quad \mathrm{~h}_{\mathrm{Vb}}^{+}+\mathrm{OH}^{-} \rightarrow{ }^{\bullet} \mathrm{OH}$

475 In comparison to using $\mathrm{Co}-\mathrm{NZF}$ alone, the $\mathrm{Co}-\mathrm{NZF} / \mathrm{K}_{2} \mathrm{~S}_{2} \mathrm{O}_{8}$ system showed less 476 degradation. $\mathrm{K}_{2} \mathrm{~S}_{2} \mathrm{O}_{8}$ is available in the form of $\mathrm{S}_{2} \mathrm{O}_{8}{ }^{2-}$ in a wide $\mathrm{pH}$ range between 2 and 14 due 477 to its low $\mathrm{pKa}=-1.30$ and may firmly attach to the positively charged catalyst's surface $\left(\mathrm{pH}_{\mathrm{pzc}}\right.$ $478=6.69)$ at $\mathrm{pH} 3$, decreasing $\mathrm{MZ}$ adsorption for photocatalytic degradation. Based on these findings, 479 we can deduce that while photolysis and oxidants play minor roles in MZ degradation individually, 480 the synergistic effects of photocatalysis $\left(\mathrm{Co}-\mathrm{NZF} / \mathrm{H}_{2} \mathrm{O}_{2} / \mathrm{UV}\right)$ are critical. 


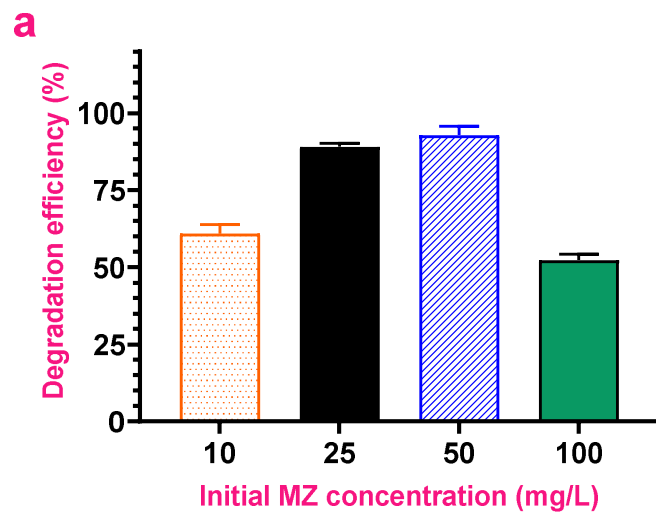

b

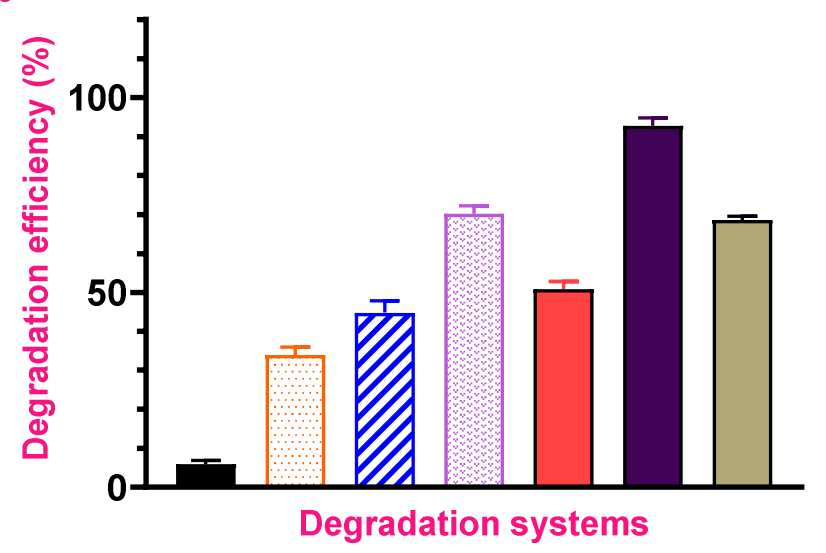

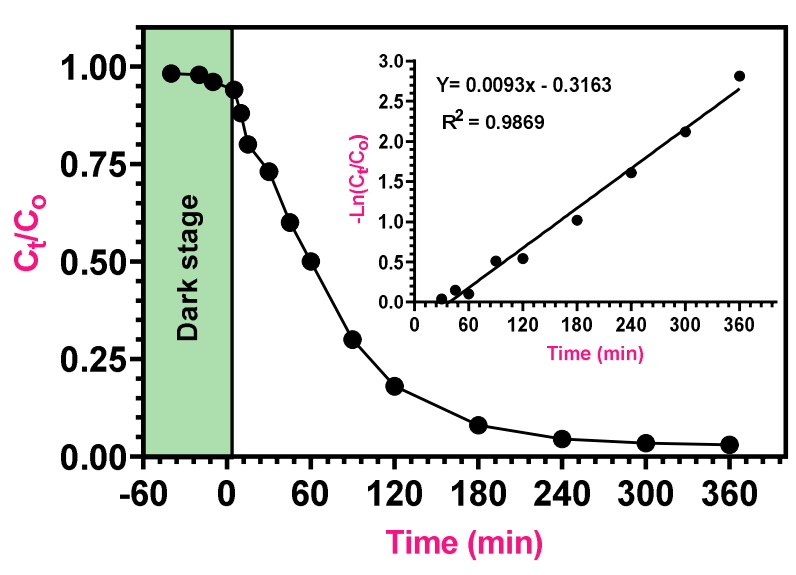

Co-NZF dark @ 12 h

- UV light alone

四 $\mathrm{H}_{2} \mathrm{O}_{2}$

च $\mathrm{K}_{2} \mathrm{~S}_{2} \mathrm{O}_{8}$

- Co-NZF/K $/ \mathrm{K}_{2} \mathrm{~S}_{2} \mathrm{O}_{8}$

Co-NZF/ $/ \mathrm{H}_{2} \mathrm{O}_{2}$

a Co-NZF

Fig.5: (a) Degradation efficiencies of Co-NZF based on initial MZ concentration (b) degradation efficiencies of various processes (c) degradation of $\mathrm{MZ}$ as a function of $\mathrm{UV}$ irradiation time using $\mathrm{Co}-\mathrm{NZF} / \mathrm{H}_{2} \mathrm{O}_{2}$ (inset: kinetic linear simulation curve). Reaction conditions: $\mathrm{K}_{2} \mathrm{~S}_{2} \mathrm{O}_{8}=5 \mathrm{mM}$; $\mathrm{H}_{2} \mathrm{O}_{2}=4 \mathrm{mM}$; Co-NZF dosage $=10 \mathrm{mg} ; \mathrm{MZ}$ vol. $=25 \mathrm{~mL} ; \mathrm{pH}=3$ and $360 \mathrm{~min}$.

The electrical energy consumed per order, coefficient of determination $\left(R^{2}\right)$ values, treatment cost, half-life $\left(t_{50 \%}\right)$ corresponding to $50 \% \mathrm{MZ}$ degradation efficiency and rate constant $\left(k_{o b s}, \min ^{-1}\right.$ ) of the pseudo-first order model are listed in Table 2. The $R^{2}$ values in the MTZ concentration range studied were greater than 0.97 , showing that the photocatalytic degradation of MZ using Co-NZF follows pseudo-first-order kinetics. When the MZ concentration was increased from 50 to $100 \mathrm{mg} \mathrm{L}^{-1}$, the rate constant reduced from 0.0117 to $0.0074 \mathrm{~min}^{-1}$. This decrease, according to Arghavan et al. 2021, is due to a larger concentration of intermediate products, which 
495 limits interaction with active hydroxyl radicals, decreasing the rate constant. In addition, a cost

496 estimate based on a $0.05 \$$ per kWh electricity price in the Turkish Republic of Northern Cyprus in

4972021 shows that the $\mathrm{E}_{\mathrm{EO}}$ value for $50 \mathrm{mg} \mathrm{L}^{-1} \mathrm{MZ}$ solution is roughly 2 times lower than that for

$498 \quad 100 \mathrm{mg} \mathrm{L}^{-1}$.

499

500 Table 2: Comparative MZ degradation efficiency of Co-NZF and other catalysts 501

\begin{tabular}{|c|c|c|c|c|c|c|c|c|}
\hline \#Process & $\mathrm{pH}$ & $\begin{array}{l}\text { MZ Conc. } \\
\left(\mathrm{mg} \mathrm{L}^{-1}\right)\end{array}$ & $\begin{array}{l}\text { "Time } \\
\text { (min) }\end{array}$ & $\begin{array}{c}k_{o b s} \\
\left(\min ^{-1}\right)\end{array}$ & $\begin{array}{l}{ }_{t_{50 \%}} \\
(\mathrm{~min})\end{array}$ & $\mathrm{R}^{2}$ & $\begin{array}{c}\eta \\
(\%)\end{array}$ & $\begin{array}{c}\mathrm{E} \\
\left(\mathrm{kWh} \mathrm{m}^{-3}\right)\end{array}$ \\
\hline $\mathrm{Co}-\mathrm{NZF} / \mathrm{H}_{2} \mathrm{O}_{2}$ & 3 & 50 & 360 & 0.0093 & 74.5 & 0.987 & 92.8 & 17.11 \\
\hline $\mathrm{Co}-\mathrm{NZF} / \mathrm{H}_{2} \mathrm{O}_{2}$ & 3 & 100 & 360 & 0.0062 & 111.8 & 0.976 & 52.3 & 25.78 \\
\hline${ }^{\mathrm{i}} \mathrm{Ag}-d-\mathrm{NZF} / \mathrm{H}_{2} \mathrm{O}_{2}$ & 3 & 50 & 360 & 0.0103 & 67.3 & 0.997 & 99.9 & 26.84 \\
\hline${ }^{\mathrm{ii}} \mathrm{MnFe}-\mathrm{LDO}$-biochar $/ \mathrm{K}_{2} \mathrm{~S}_{2} \mathrm{O}_{8}$ & 3 & 20 & 240 & 0.212 & 3.27 & 0.996 & 92.1 & 11.31 \\
\hline${ }^{\mathrm{ii}} \mathrm{MnFe}-\mathrm{LDO}$-biochar $/ \mathrm{H}_{2} \mathrm{O}_{2}$ & 3 & 20 & 240 & 0.0868 & 7.98 & 0.987 & 99.0 & 10.26 \\
\hline iiiUV/BiOI-MWCNTs & 7 & 10 & 90 & 0.0740 & 9.36 & 0.952 & 99.9 & 32.09 \\
\hline${ }^{\mathrm{iv}} \mathrm{FeNi}_{3} /$ chitosan/BiOI & 7 & 20 & 200 & 0.0092 & 75.3 & 0.983 & 100 & - \\
\hline${ }^{\mathrm{v}} \mathrm{N}-\mathrm{TiO}_{2} / \mathrm{ZnFe}_{2} \mathrm{O}_{4} /$ zeolite $/ \mathrm{O}_{3}$ & 5 & 100 & 120 & 0.0196 & 35.6 & 0.998 & 94 & - \\
\hline vi $25 \% \mathrm{BiVO}_{4} / \mathrm{BiPO}_{4}$ & - & 5 & 120 & 0.0203 & 34.1 & - & 90 & - \\
\hline
\end{tabular}

$502 \quad{ }^{\#}$ Each process is under UV irradiation at a given reaction time. $\mathrm{t}_{50 \%}=0.693 / \mathrm{k}_{\mathrm{obs}}$.

503 i: Mustafa and Oladipo 2021; ii: Azalok et al.2021b; iii: Balarak et al. 2019; iv: Arghavan et al. 2021;

504 v: Aram et al. 2020; vi: Yunhui et al.2019.

505

506

507

508

509

510

Active radicals trapping test and metronidazole $U V$-catalytic degradation mechanism

511 MZ degradation process. The application of BQ under the same optimum conditions significantly

512 hampered the $\mathrm{Co}-\mathrm{NZF}$ degradation efficiency, resulting in $64.7 \% \mathrm{MZ}$ degradation compared to

$51392.8 \%$ without the BQ. In the presence of $t$ - $\mathrm{BuOH}$ and $\mathrm{Na}-\mathrm{Ox}$, respectively, the degradation

514 efficiency decreased to $77.6 \%$ and $81.7 \%$. The results revealed that ${ }^{\circ} \mathrm{O}_{2}{ }^{-}$was the most prevalent

515 radical; this is most likely owing to active defects in the $\mathrm{Co}-\mathrm{NZF}$ structure, which are responsible

516 for $\mathrm{O}_{2}$ adsorption and reduction to generate reactive oxygen species (ROS) ${ }^{\bullet} \mathrm{O}_{2}^{-}$. Both ${ }^{\bullet} \mathrm{OH}$ radicals

517 and photoinduced holes $\left(h^{+}\right)$contributed to the decomposition processes. 

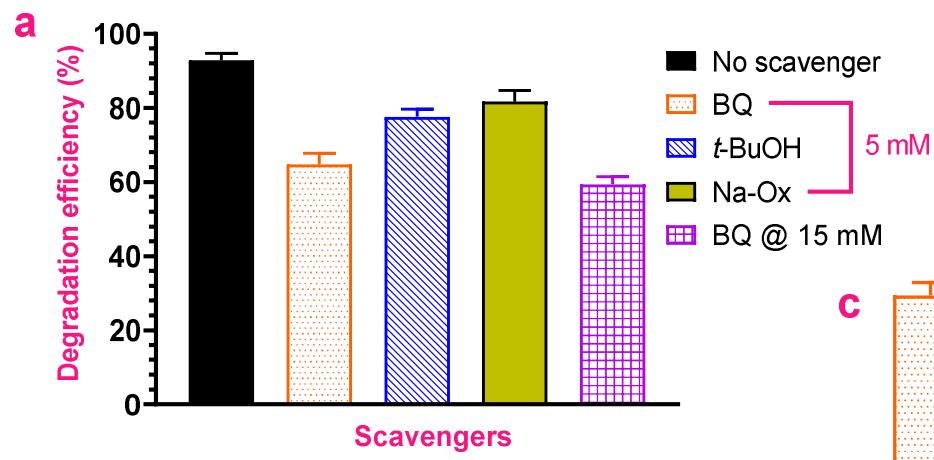

b
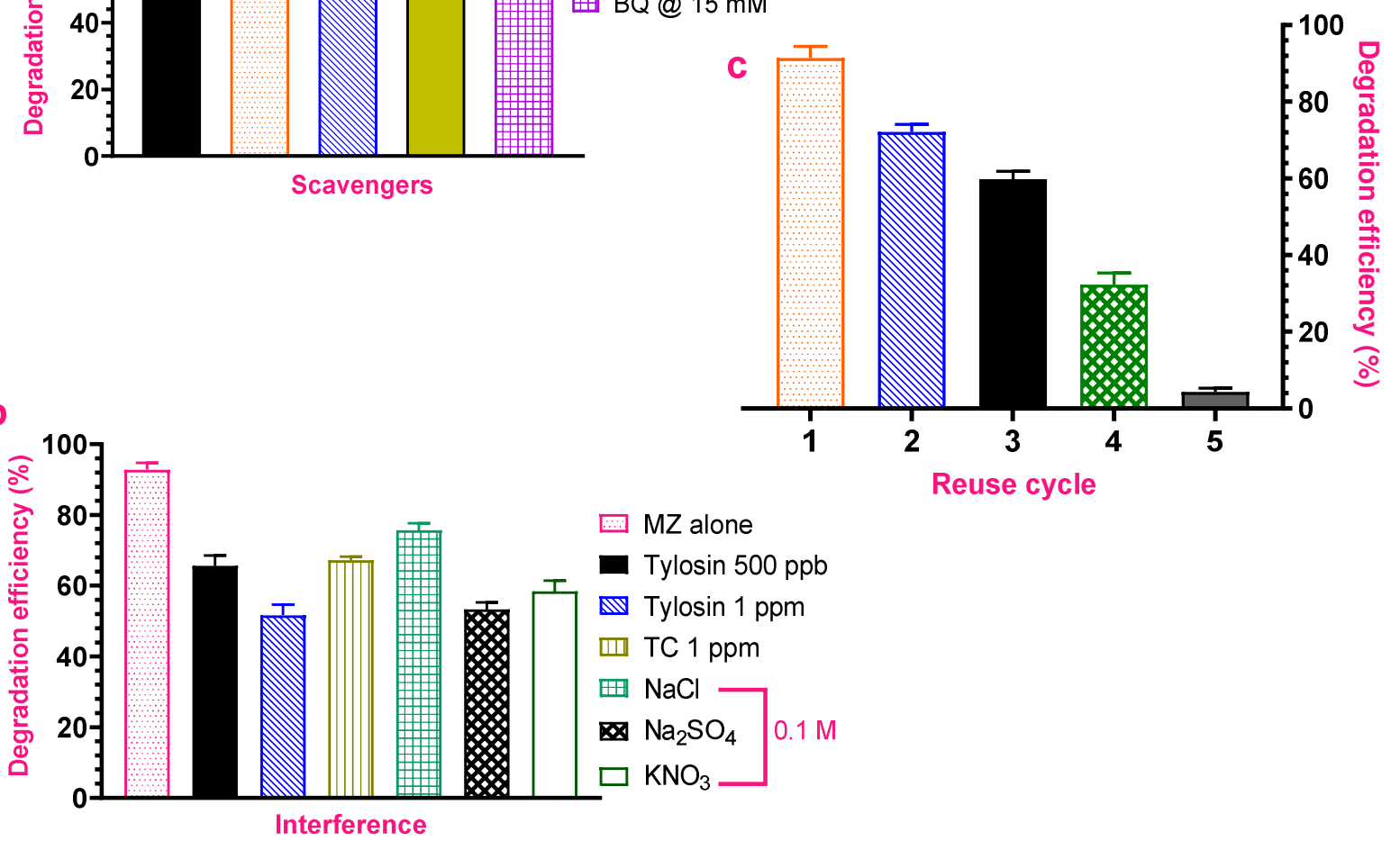

519 Fig.6: (a) Active radicals quenching during degradation process (b) performance of Co-NZF in 520 presence of interfering species (c) $\mathrm{Co}-\mathrm{NZF}$ reuse studies. Reaction conditions: $\mathrm{pH}=3$, catalyst 521 dosage $=10 \mathrm{mg}$ and $\mathrm{MZ}$ initial concentration $=50 \mathrm{mgL}^{-1}$ under $360 \mathrm{~min}$ UV illumination.

522

523 Considering the radical scavenging results and UV-vis DRS data, the likely mechanism of MZ

524 photodegradation by $\mathrm{Co}-\mathrm{NZF}$ is postulated. Eqs. 11 and 12 were used to calculate the conduction 525 band $\left(\mathrm{C}_{b}\right)$ and valence band $\left(\mathrm{V}_{b}\right)$ potentials of $\mathrm{Co}-\mathrm{NZF}$, which were found to be $-0.53 \mathrm{eV}$ and 2.31

$526 \mathrm{eV}$, respectively; and $\chi$ represents the calculated absolute electronegativity of $\mathrm{Co}-\mathrm{NZF}$.

$527 \quad C_{b}=V_{b}-E_{g}$

$528 V_{b}=\chi+0.5 E_{g}-4.5 \mathrm{eV}$ 
531 photon energy greater than that of its bandgap. As indicated in Eq.8, this mechanism produces

532 electron $\left(e^{-}\right)$-holes $\left(h^{+}\right)$in the exterior shell of $\mathrm{Co}^{-} \mathrm{NZF}$, which generates extremely reactive 533 radicals by oxidizing $\mathrm{O}_{2}$ and $\mathrm{H}_{2} \mathrm{O}$ molecules as shown in Eqs. 13-14.

$534 \mathrm{Co}-\mathrm{NZF}-\mathrm{O}_{2}($ adsorbed $)+\mathrm{e}_{\mathrm{Cb}}^{-} \rightarrow{ }^{\bullet} \mathrm{O}_{2}^{-}$

$535 \mathrm{~h}_{\mathrm{Vb}}^{+}+\mathrm{H}_{2} \mathrm{O} \rightarrow{ }^{\bullet} \mathrm{OH}+\mathrm{H}^{+}$

536 This is thermodynamically feasible because $\mathrm{Co}-\mathrm{NZF}$ 's $\mathrm{C}_{b}$ is more negative than the reduction 537 potential of $\mathrm{O}_{2} /{ }^{\circ} \mathrm{O}_{2}^{-}\left(-0.33 \mathrm{eV}\right.$ vs. NHE) and its $\mathrm{V}_{\mathrm{b}}$ is more positive than $\left({ }^{\circ} \mathrm{OH} / \mathrm{H}_{2} \mathrm{O}, 2.10 \mathrm{eV} v s\right.$. 538 NHE) (Karimi et al. 2019; Ekande and Kumar, 2021; Oladipo 2021ab). If no suitable charge carrier 539 scavengers are available, the generated $e^{-}$and $h^{+}$pairs recombine, generating heat; however, $\mathrm{MZ}$ 540 molecules can be degraded if charge separation is established. Because of its localized surface 541 plasmon resonance effect (Braik et al. 2021; Sinha 2021; Debnath et al. 2021), the Co dopant can 542 act as an electron reservoir and delayed the recombination of photoinduced charge carriers as 543 validated by the results of the PL investigation. Also, the conversion between $\mathrm{Co}^{3+}$ and $\mathrm{Co}^{2+}(1.81$ $544 \mathrm{~V} v s$ NHE) gives priority to capture electrons, hence can inhibit electron-hole pair recombination 545 (Hu et al. 2018). Based on the results of the radical quenching studies, the ${ }^{\circ} \mathrm{O}_{2}{ }^{-}$radicals and the 546 photogenerated charge carriers can either directly degrade the adsorbed $\mathrm{MZ}$ or react with $\mathrm{H}_{2} \mathrm{O}_{2}$ in 547 the system to form ${ }^{\circ} \mathrm{OH}$ radicals, as represented in Eqs. 15-16 and Scheme 3.

$549 \mathrm{O}_{2}^{\bullet-}+\mathrm{H}_{2} \mathrm{O}_{2} \rightarrow{ }^{\bullet} \mathrm{OH}+\mathrm{OH}+\mathrm{O}_{2}$

$550 \mathrm{~h}_{\mathrm{VB}}^{+} / \mathrm{O}_{2}^{\bullet-} /{ }^{\bullet} \mathrm{OH}+\mathrm{MZ} \stackrel{{ }^{\circ} \mathrm{MZ}}{\longrightarrow}$ degradedproducts 


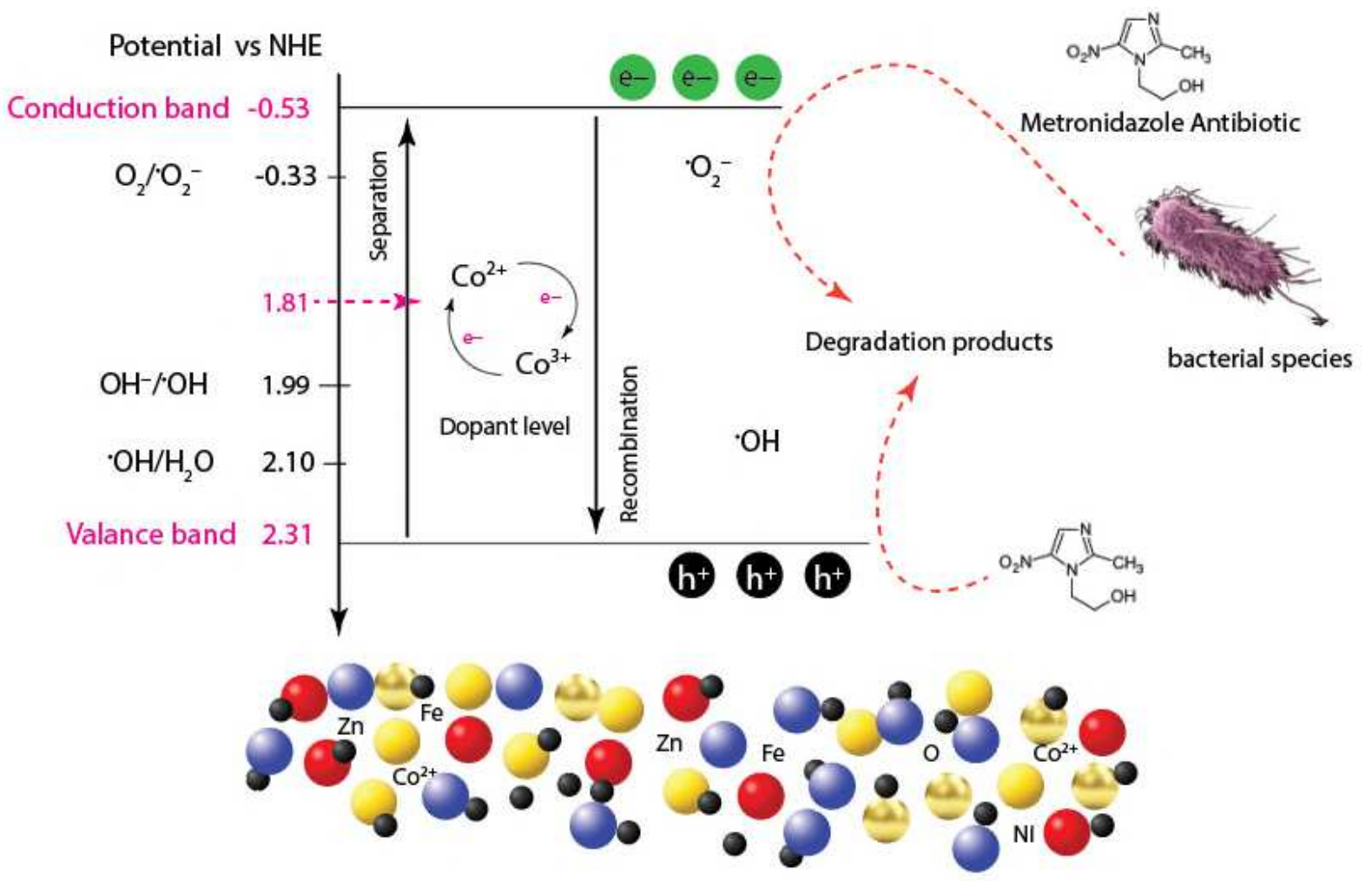

Surface of Co-NZF catalyst upon exposure to UV-light

Scheme 3: Probable MZ degradation and bacterial disinfection mechanisms of Co-NZF

\section{Effect of interference on degradation performance and reusability of Co-NZF}

Under optimal conditions, different salts $\left(\mathrm{Na}_{2} \mathrm{SO}_{4}, \mathrm{KNO}_{3}\right.$ and $\left.\mathrm{NaCl}\right)$ and antibiotics (tetracycline and tylosin) were added into the system as interference. In the presence of ionic salts and antibiotics, the $\mathrm{Co}-\mathrm{NZF}$ degradation efficiency decreased to $53.3-75.4 \%\left(\mathrm{SO}_{4}{ }^{2-}>\mathrm{NO}_{3}{ }^{-}>\mathrm{Cl}^{-}\right)$ and 51.7-67.3\%, respectively, after $360 \mathrm{~min}$ of interaction (Fig.6b). The size of the interfering species, the magnitude of the surface charge, and the generation of less reactive species may all contribute to the inhibition of Co-NZF. Tylosin and tetracycline, in particular, have a molecular 
567 weight of $\sim 5.4$ and 2.6 times that of the MZ, respectively. As a result, their adsorption on the

568 surface of Co-NZF could prevent MZ from adsorbing further. The hydroxyl radicals are

569 scavenged by sulphate, chloride, and nitrate ions, resulting in the formation of less reactive

570 inorganic species such as $\mathrm{NO}_{2}{ }^{\circ}, \mathrm{Cl}^{\bullet-}, \mathrm{SO}_{4}{ }^{--}$and $\mathrm{Cl}_{2}{ }^{--}$(Devi et al. 2013); hence, $\mathrm{MZ}$ degradation

571 was subsequently reduced as a result of this. The Co-NZF was effectively recycled for five

572 photocatalytic reuse cycles and retained more than $50 \%$ after the third cycle but the performance

573 decreased remarkably beyond this stage (Fig. 6c). This decrease in degradation efficiency could

574 be related to the diminishing reactive sites and $\mathrm{Co}^{-} \mathrm{NZF}$ concentration in the bulk solution as a

575 result of sequential separation, filtration, and washing operations.

576

577

578

579

580

581

582

583

584

585

586

587

588

589

590

\section{Bacterial disinfection activity performance of $\mathrm{Co}-\mathrm{NZF}$}

The in vitro antibacterial activity of $\mathrm{Co}-\mathrm{NZF}$ against $S$. aureus and $E$. coli at different dosages are shown in Fig.7; the viability curves were created by counting colony-forming units (CFU). Co-NZF displayed bacteriostatic and bactericidal effects after 60-180 min of UV light irradiation against the bacterial colonies, as seen in time-kill studies in Fig. $7 \mathrm{a}-$ b. At $5-25 \mathrm{mg} \mathrm{mL}^{-1}, \mathrm{Co}-\mathrm{NZF}$ was bacteriostatic against both bacterial species for the first 180 min afterwards then exhibited bactericidal effects. In comparison to the control (without $\mathrm{Co}-\mathrm{NZF}$ ), 41.1, 66.8, and 74.1\% E. coli degradation were obtained in the first $60 \mathrm{~min}$ in the presence of 5,15 , and $25 \mathrm{mg} \mathrm{mL}^{-1}$ $\mathrm{Co}-\mathrm{NZF} / \mathrm{UV}$ system, respectively. But when the time was extended to $120 \mathrm{~min}$; both 15 and 25 $\mathrm{mg} \mathrm{mL}^{-1}$ of Co-NZF inactivated nearly $98 \%$ of the E. coli colonies (Fig.7a). After $120 \mathrm{~min}$ (Fig.7b), $5 \mathrm{mg}$ of $\mathrm{Co}^{-} \mathrm{NZF}$ had a bactericidal effect against $S$. aureus, which was most likely owing to the interaction of the positively charged $\mathrm{Co}-\mathrm{NZF}^{+}$with the bacteria proteins or/and the induction of ROS, which resulted in bacterial death. 

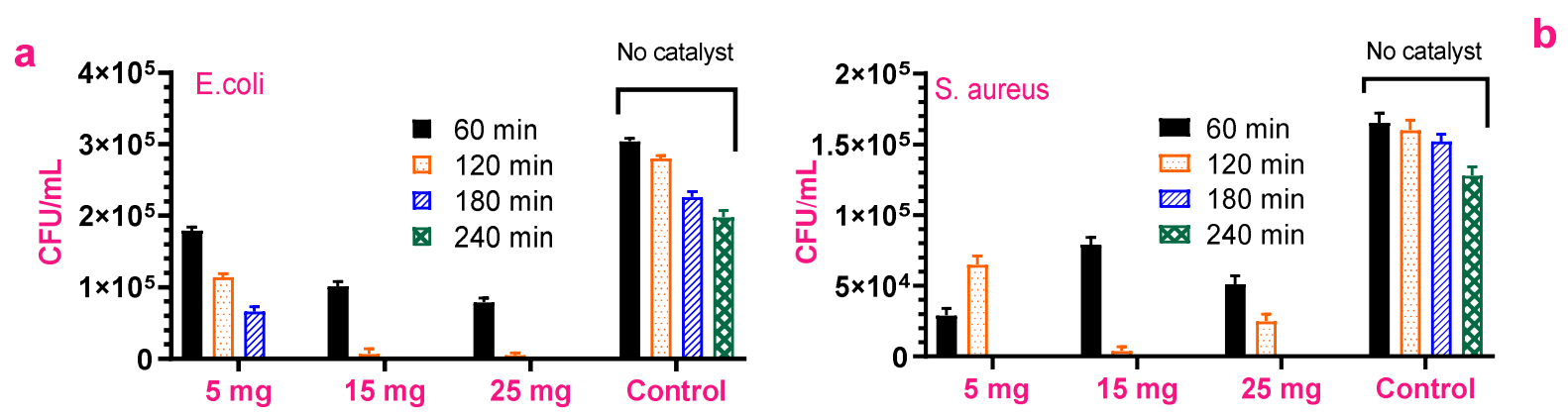

C
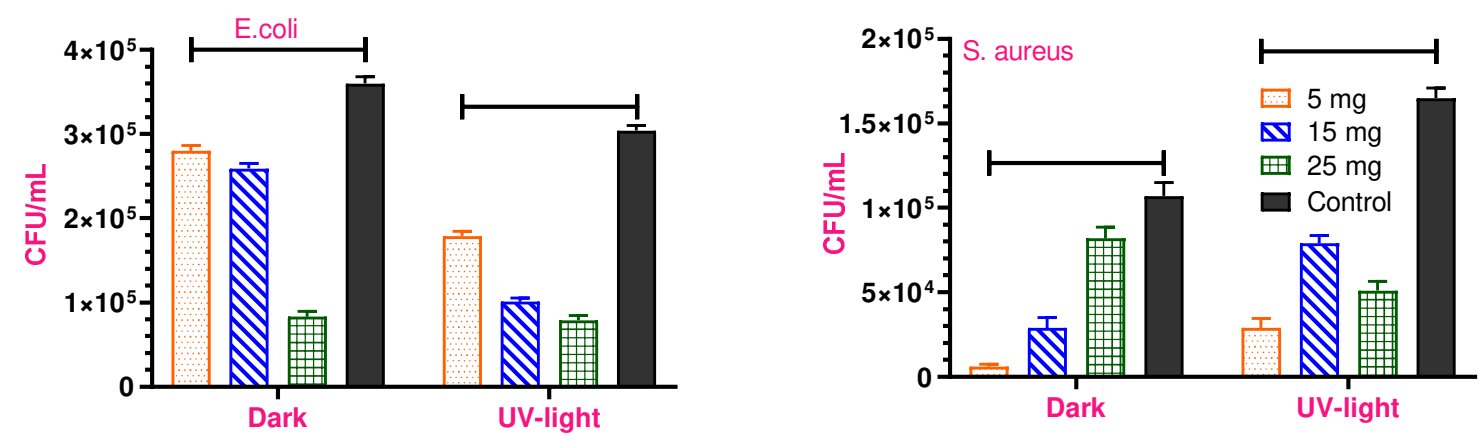

591

592

593

594

595

596

597

598

599

600

601

602

603

604

605

606
Fig.7: Time-kill assays as a function of Co-NZF doses for inhibition of E. coli and S. aureus under UV-light assisted inhibition (a and b); $\mathbf{c}$ and $\mathbf{d}$ show antibacterial inhibition performance of $\mathrm{Co}^{-} \mathrm{NZF}$ in the dark and under UV in $60 \mathrm{~min}$.

The performance of $\mathrm{Co}-\mathrm{NZF}$ was examined after $60 \mathrm{~min}$ in the absence and presence of UV light to further understand the contribution of UV light during the bacteria degradation process (Fig.8). After $60 \mathrm{~min}$, without UV light irradiation, 5, 15, and $25 \mathrm{mg} \mathrm{mL}^{-1}$ of Co-NZF showed 22.2, 28.1, and $76.9 \%$ degradation efficiency, respectively, as shown in Fig.7c for E. coli. When the Co-NZF dosage was increased from 5 to $15 \mathrm{mg} \mathrm{mL}^{-1}$, the degradation efficiency of $S$. aureus in the dark decreased from $94.4 \%$ to $72.9 \%$. Only $23.4 \%$ bacterial degradation efficiency was attained when the dose was increased to $25 \mathrm{mg} \mathrm{mL}^{-1}$ (Fig.7d). Suggesting that $5 \mathrm{mg}$ of Co-NZF is sufficient to remarkably inactivate $S$. aureus in the dark condition. It is worthy to note that under both the dark 
and UV-light conditions; Co-NZF demonstrated better antibacterial action against $S$. aureus

608

609

610

612

613

614

615

616

617

618

619

620

621

622

623

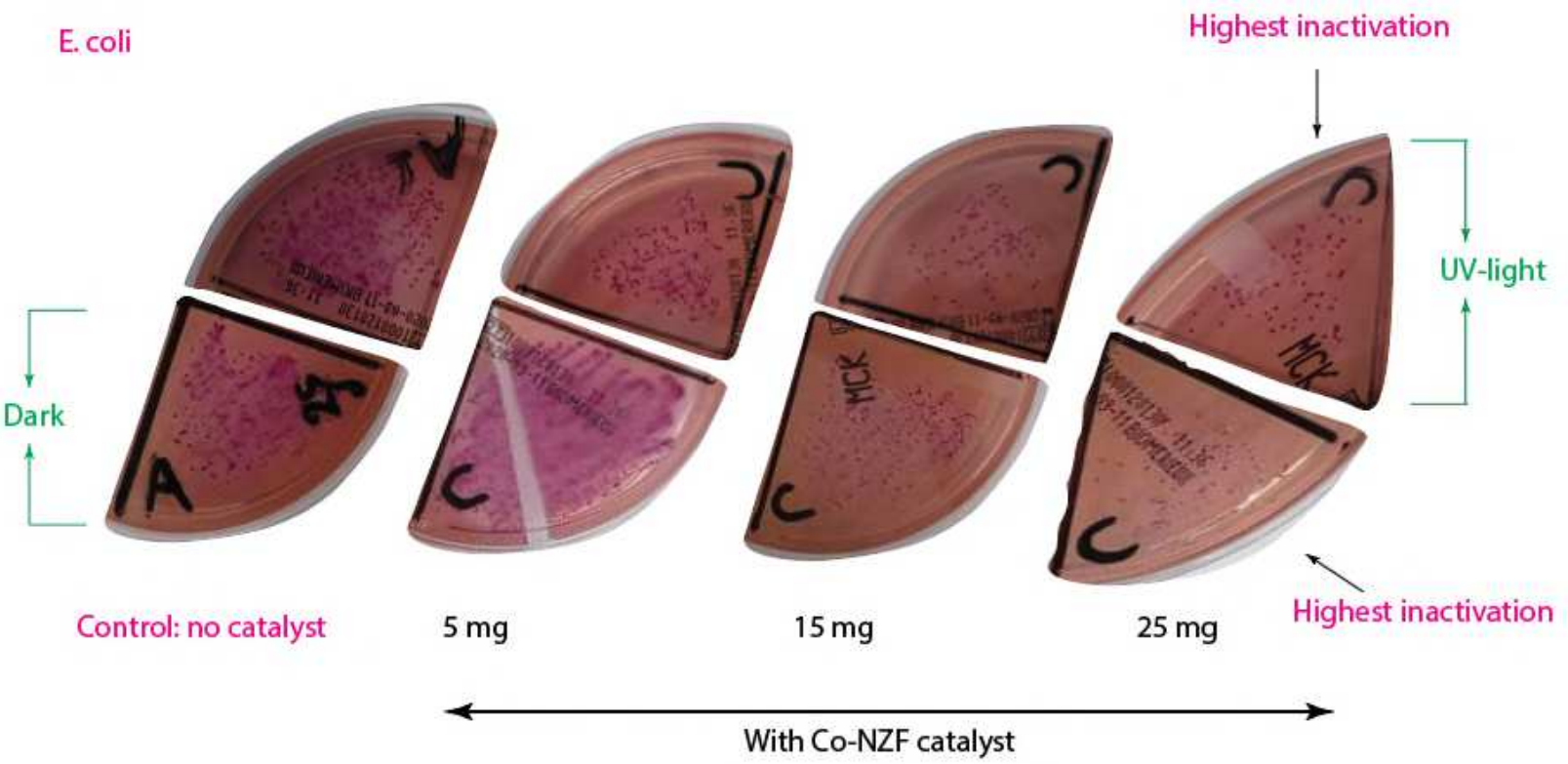

strains than $E$. coli strains, which could be attributed to differences in their composition and cell membrane structure.

With Co-NZF catalyst
Fig.8: Comparative performance of varying doses of $\mathrm{Co}-\mathrm{NZF}$ against Escherichia coli in the dark and UV-light after 60 min catalyst exposure.

Different mechanisms for the bactericidal effects of ferrites and metal oxides have been proposed in previous investigations (Asadi et al. 2019; Aali et al. 2019; Mizwari et al. 2021; Mmelesi et al. 2021). According to Méndez-Pfeiffer et al. 2019, atomic force microscopy images revealed damage to the E. coli cellular wall in the presence of photoactivated Ag nanoparticles.

They believe that the Ag NPs' positive charge can easily interact with the phosphate groups of the bacteria membrane's phospholipids and penetrate the bacteria, causing the membrane to rupture and release the cellular contents. In line with their report, the antibacterial activity of the $\mathrm{Co}-\mathrm{NZF}$ in the dark, herein, is likely due to the interaction of positively charged metal ions in the catalyst's external shell with sulfhydryl groups and phosphorus-containing compounds in the bacterial cell 
624 membrane, causing damage to the DNA's replication potential. The enhanced antibacterial activity

625 of $\mathrm{Co}^{-\mathrm{NZF}}$ under UV light could be related to the production of reactive oxygenated species,

626 which damaged the membrane and caused cell death.

627

628 Conclusion

$629 \mathrm{Ni}-\mathrm{Zn}$ ferrites (NZF) were synthesized using a slightly modified co-precipitation procedure and 630 then doped with $\mathrm{Co}^{2+}$ ions to produce an effective photocatalyst $(\mathrm{Co}-\mathrm{NZF})$ for decontamination 631 of bacterial-contaminated and metronidazole antibiotic (MZ) water. Both NZF and Co-NZF were 632 characterized using various spectroscopic and electrochemical tools. Co-NZF has a bandgap of $6332.84 \mathrm{eV}$, an average crystallite size of $25.6 \mathrm{~nm}$, a specific surface area of $70.2 \mathrm{~m}^{2} \mathrm{~g}^{-1}$, total pore 634 volume of $0.298 \mathrm{~cm}^{3} \mathrm{~g}^{-1}$, spongy morphology with agglomerated irregular grain, and can be easily 635 separated from the solution by an external magnet, according to the results. The use of Co doping 636 resulted in an increase in impurity levels, which helped to separate and transport photogenerated 637 electron-hole pairs more effectively. Also, $\mathrm{Co}-\mathrm{NZF}$ had the highest photocurrent intensity and 638 smallest arc radius $\left(\mathrm{R}_{c t}\right)$ which decreased its electron transfer impedance with increased charge 639 mobility due to the variation in ionic and electronic conductivity induced by Co incorporation.

$64110 \mathrm{mg}$ of $\mathrm{Co}-\mathrm{NZF}$ degraded $92.8 \%$ of the $\mathrm{MZ}$ with a rate constant of $0.0093 \mathrm{~min}^{-1}$ and consumed 642 total electrical energy of $17.11 \mathrm{kWh} \mathrm{m}^{-3}$. Even in the presence of very high molecular weight 643 antibiotic interferences, the catalyst retained more than $50 \%$ of its performance with adequate 644 reuse efficiency. Notably, $15 \mathrm{mg} \mathrm{Co}-\mathrm{NZF}$ achieved a complete inhibition of both E. coli and $S$. 645 aureus strains when photoactivated for $180 \mathrm{~min}$. In the dark, 5 and $25 \mathrm{mg}$ of Co-NZF exhibited $64694.4 \%$ and $77 \%$ bacteriostatic effects on S. aureus and E. coli, respectively within 60 min. 
661

662

663

664

665

666

667

668

669

670

671

672

673

674

675

676

Authors' contributions All authors contributed to the conceptualization, read and approved the final manuscript. FSM performed the experiments, collected and analyzed the data. AAO formulated the research ideas, designed the methodology, interpreted the data and was a major contributor in writing the manuscript. ZMM characterized the synthesized materials and interpreted results. MG provided reagents, instrumentation and administration.

Data availability The datasets used and/or analysed during the current study are available from the corresponding author on reasonable request.

\section{Declarations}

Competing interests The authors declare that they have no competing interests.

Ethics approval and consent to participate Not applicable.

Consent for publication Not applicable.

Funding Not applicable.

\section{References}

Aali H, Azizi N, Baygi NJ, et al (2019) High antibacterial and photocatalytic activity of solution combustion synthesized $\mathrm{Ni}_{0.5} \mathrm{Zn}_{0.5} \mathrm{Fe}_{2} \mathrm{O}_{4}$ nanoparticles: Effect of fuel to oxidizer ratio and complex fuels. Ceram Int 45: 19127-19140. https://doi.org/10.1016/j.ceramint.2019.06.159

Abureesh MA, Oladipo AA, Mizwari ZM, Berksel E (2018) Engineered mixed oxide-based polymeric composites for enhanced antimicrobial activity and sustained release of antiretroviral drug. Int J Biol Macromol 116: 417-425. https://doi.org/10.1016/j.ijbiomac.2018.05.065

Ahmad M, Ahmad I, Ahmed E, et al (2020) Facile and inexpensive synthesis of Ag doped 
702

$\mathrm{ZnO} / \mathrm{CNT}$ composite: Study on the efficient photocatalytic activity and photocatalytic mechanism. J Mol Liq 311:113326. https://doi.org/10.1016/j.molliq.2020.113326.

Aram M, Farhadian M, Solaimany Nazar AR, et al (2020) Metronidazole and Cephalexin degradation by using of $\mathrm{Urea} / \mathrm{TiO}_{2} / \mathrm{ZnFe}_{2} \mathrm{O}_{4} / \mathrm{Clinoptiloite}$ catalyst under visible-light irradiation and ozone injection. J Mol Liq 304:112764. https://doi.org/10.1016/j.molliq.2020.112764

Arghavan FS, Al-Musawi TJ, Rumman GA, Pelalak R, Khataee A, Nasseh N (2021) Photocatalytic performance of a nickel ferrite/chitosan/bismuth(III) oxyiodide nanocomposite for metronidazole degradation under simulated sunlight illumination. $\mathbf{J}$ Environ Chem Eng 9: 105619. https://doi.org/10.1016/j.jece.2021.105619

Asadi S, Moeinpour F (2019) Inactivation of Escherichia coli in water by silver-coated $\mathrm{Ni}_{0.5} \mathrm{Zn}_{0.5} \mathrm{Fe}_{2} \mathrm{O}_{4}$ magnetic nanocomposite: a Box-Behnken design optimization. Appl Water Sci 9:23. https://doi.org/10.1007/s13201-019-0901-4

Azalok KA, Oladipo AA, Gazi M (2021a) UV-light-induced photocatalytic performance of reusable MnFe-LDO-biochar for tetracycline removal in water. J Photochem Photobiol A Chem 405: 112976. https://doi.org/10.1016/j.jphotochem.2020.112976

Azalok KA, Oladipo AA, Gazi M (2021b) Hybrid MnFe-LDO-biochar nanopowders for degradation of metronidazole via UV-light-driven photocatalysis: Characterization and $\begin{array}{llll}\text { mechanism } & \text { studies. } & \text { Chemosphere } & \text { 268: }\end{array}$ https://doi.org/10.1016/j.chemosphere.2020.128844

Balarak D, Igwegbe CA, Onyechi PC (2019) Photocatalytic degradation of metronidazole using BIOI-MWCNT composites: synthesis, characterization, and operational parameters. Sigma J Eng Nat Sci 37: 1235-1249.

Bajorek A, Berger C, Dulski M, et al (2019) Microstructural and magnetic characterization of 
$\mathrm{Ni}_{0.5} \mathrm{Zn}_{0.5} \mathrm{Fe}_{2} \mathrm{O}_{4}$ ferrite nanoparticles. J Phys Chem Solids 129:1-21. https://doi.org/10.1016/j.jpcs.2018.12.045.

Bashiri F, Khezri SM, Kalantary RR, Kakavandi B (2020) Enhanced photocatalytic degradation of metronidazole by $\mathrm{TiO} 2$ decorated on magnetic reduced graphene oxide: Characterization, optimization and reaction mechanism studies. J Mol Liq 314: 113608. https://doi.org/10.1016/j.molliq.2020.113608

Bokare A, Sanap A, Pai M, et al (2013) Antibacterial activities of Nd doped and Ag coated $\mathrm{TiO}_{2}$ nanoparticles under solar light irradiation. Colloids Surfaces B Biointerfaces 102: 273280. https://doi.org/10.1016/j.colsurfb.2012.08.030

Braik M, Sow I, Nelayah J, et al (2021) Introducing cobalt as a potential plasmonic candidate combining optical and magnetic functionalities within the same nanostructure. Nanoscale13: 2639-2647. https://doi.org/10.1039/d0nr06966c

Chan R, Wandee S, Wang M, et al (2020) Fate, transport and ecological risk of antibiotics from pig farms along the bang pakong River, Thailand. Agric Ecosyst Environ 304:107123. https://doi.org/10.1016/j.agee.2020.107123

Chahal S, Singh S, Kumar A, Kumar P (2020) Oxygen-deficient lanthanum doped cerium oxide nanoparticles for potential applications in spintronics and photocatalysis. Vacuum 177: 109395. https://doi.org/10.1016/j.vacuum.2020.109395.

Chen CC, Jaihindh D, Hu SH, Fu YP (2017) Magnetic recyclable photocatalysts of Ni-Cu-Zn ferrite@SiO $\mathrm{Si}_{2} @ \mathrm{TiO}_{2} @ \mathrm{Ag}$ and their photocatalytic activities. J Photochem Photobiol A Chem 334:74-85. https://doi.org/10.1016/j.jphotochem.2016.11.005

Chen F, Yang Q, Wang D, et al (2018) Highly-efficient degradation of amiloride by sulfate radicals-based photocatalytic processes: Reactive kinetics, degradation products and mechanism. Chem Eng J 354:983-994. https://doi.org/10.1016/j.cej.2018.08.095 
754

763

Dadgostar P (2019) Antimicrobial resistance: implications and costs. Infect. Drug Resist 12: 39033910. https://dx.doi.org/10.2147\%2FIDR.S234610

Debnath S, Das A, Das R (2021) Effect of cobalt doping on structural parameters, cation distribution and magnetic properties of nickel ferrite nanocrystals. Ceram Int 47: 1646716482. https://doi.org/10.1016/j.ceramint.2021.02.095

Devi LG, Munikrishnappa C, Nagaraj B, Rajashekhar KE (2013) Effect of chloride and sulfate ions on the advanced photo Fenton and modified photo Fenton degradation process of Alizarin Red S. J Mol Catal A Chem 374-375:125-131. https://doi.org/10.1016/j.molcata.2013.03.023

Džunuzović AS, Ilić NI, Vijatović Petrović MM, et al (2015) Structure and properties of Ni-Zn ferrite obtained by auto-combustion method. J Magn Magn Mater 374: 245-251. https://doi.org/10.1016/j.jmmm.2014.08.047

Ekande SO, Kumar M (2021) Facile synthesis of graphitic carbon nitride from acetic acid pretreatment to activate persulfate in presence of blue light for photocatalytic removal of metronidazole. Chemosphere.

276:

130171. https://doi.org/10.1016/j.chemosphere.2021.130171

Elmolla ES, Chaudhuri M (2010) Comparison of different advanced oxidation processes for treatment of antibiotic aqueous solution. Desalination 256: 43-47. https://doi.org/10.1016/j.desal.2010.02.019

Estrada-Flórez SE, Serna-Galvis EA, Torres-Palma RA (2020) Photocatalytic vs. sonochemical removal of antibiotics in water: Structure-degradability relationship, mineralization, antimicrobial activity, and matrix effects. J Environ Chem Eng 5:104359. https://doi.org/10.1016/j.jece.2020.104359

Fakhravar S, Farhadian M, Tangestaninejad S (2020) Excellent performance of a novel dual Z- 
scheme $\mathrm{Cu}_{2} \mathrm{~S} / \mathrm{Ag}_{2} \mathrm{~S} / \mathrm{BiVO}_{4}$ heterostructure in metronidazole degradation in batch and continuous systems: Immobilization of catalytic particles on $\alpha-\mathrm{Al}_{2} \mathrm{O}_{3}$ fiber. Appl Surf Sci 505:144599. https://doi.org/10.1016/j.apsusc.2019.144599

Farzadkia M, Bazrafshan E, Esrafili A, et al (2015) Photocatalytic degradation of Metronidazole with illuminated $\mathrm{TiO}_{2}$ nanoparticles. J Environ Health Sci Eng 13:35-44. https://doi.org/10.1186/s40201-015-0194-y

Hena S, Gutierrez L, Croué JP (2020) Removal of metronidazole from aqueous media by C. vulgaris. J Hazard Mater 384:121400. https://doi.org/10.1016/j.jhazmat.2019.121400

Hena S, Gutierrez L, Croué JP (2021) Removal of pharmaceutical and personal care products (PPCPs) from wastewater using microalgae: A review. J. Hazard. Mater 430: 124041. https://doi.org/10.1016/j.jhazmat.2020.124041

Hu T, Li H, Du N, Hou W (2018) Iron-Doped Bismuth Tungstate with an Excellent Photocatalytic Performance. ChemCatChem 10:3040-3048. https://doi.org/10.1002/cctc.201701965.

Ifebajo AO, Oladipo AA, Gazi M (2020) Sun-light driven enhanced azo dye decontamination from aqueous solution by $\mathrm{CoO}-\mathrm{CuFe}_{2} \mathrm{O}_{4}$ derived from layered double hydroxide. Desal Water Treat 177:423-430. https://doi.org/10.5004/dwt.2020.25247

Ivanovskaya MI, Tolstik AI, Kotsikau DA et al. (2009) The structural characteristics of Zn-Mn ferrite synthesized by spray pyrolysis. Russ. J Phys Chem 83: 2081-2086. https://doi.org/10.1134/S0036024409120140

Kaphle A, Reed T, Apblett A, Hari P (2019) Doping efficiency in cobalt-doped ZnO $\begin{array}{lllll}\text { nanostructured } & \text { materials. } & \text { J } & \text { Nanomater } & \text { 2019: }\end{array}$ https://doi.org/10.1155/2019/7034620

Karimi B, Habibi MH (2019) High photocatalytic activity of light-driven $\mathrm{Fe}_{2} \mathrm{TiO}_{5}$ 
nanoheterostructure toward degradation of antibiotic metronidazole. J Ind Eng Chem 80: 292-300. https://doi.org/10.1016/j.jiec.2019.08.007.

Kefeni KK, Mamba BB (2020) Photocatalytic application of spinel ferrite nanoparticles and nanocomposites in wastewater treatment: Review. Sustain Mater Technol 23: e00140. https://doi.org/10.1016/j.susmat.2019.e00140

Li J, Zhao W, Guo Y, Wei Z, Han M, He H, Yang S, Sun C (2015) Facile synthesis and high activity of novel $\mathrm{BiVO}_{4} / \mathrm{FeVO}_{4}$ heterojunction photocatalyst for degradation of metronidazole. Appl Surf Sci 351:270-279. https://doi.org/10.1016/j.apsusc.2015.05.134

Luo Y, Mao D, Rysz M, et al (2010) Trends in antibiotic resistance genes occurrence in the Haihe River, China. Environ Sci Technol 44:7220-7225. https://doi.org/10.1021/es100233w

Manikandan A, Hema E, Durka M, et al (2015) Room Temperature Ferromagnetism of Magnetically Recyclable Photocatalyst of $\mathrm{Cu}_{1-\mathrm{x}} \mathrm{Mn}_{\mathrm{x}} \mathrm{Fe}_{2} \mathrm{O}_{4}-\mathrm{TiO}_{2} \quad(0.0 \leq \mathrm{x} \leq 0.5)$ Nanocomposites. J Supercond Nov Magn 28: 1783-1795. https://doi.org/10.1007/s10948014-2945-X.

Méndez-Pfeiffer PA, Soto Urzúa L, Sánchez-Mora E, et al (2019) Damage on Escherichia coli and Staphylococcus aureus using white light photoactivation of $\mathrm{Au}$ and $\mathrm{Ag}$ nanoparticles. J Appl Phys 125: 213102. https://doi.org/10.1063/1.5090273

Mizwari ZM, Oladipo AA, Yilmaz E (2021) Chitosan/metal oxide nanocomposites: synthesis, characterization, and antibacterial activity. Int J Polym Mater Polym Biomater 70: 383391. https://doi.org/10.1080/00914037.2020.1725753.

Mmelesi OK, Masunga N, Kuvarega A, et al (2021) Cobalt ferrite nanoparticles and nanocomposites: Photocatalytic, antimicrobial activity and toxicity in water treatment. Mater. Sci. Semicond. Process 123: 105523. https://doi.org/10.1016/j.mssp.2020.105523 
844

845

846

847

848

849

850

851

852

853

854

855

856

857

858

859

860

861

862

Mustafa FS, Oladipo AA (2021) Photocatalytic degradation of metronidazole and bacteria disinfection activity of $\mathrm{Ag}$-doped $\mathrm{Ni}_{0.5} \mathrm{Zn}_{0.5} \mathrm{Fe}_{2} \mathrm{O}_{4}$. J Water Proc Eng 42: 102132. https://doi.org/10.1016/j.jwpe.2021.102132

Nag S, Ghosh A, Das D, et al (2020) $\mathrm{Ni}_{0.5} \mathrm{Zn}_{0.5} \mathrm{Fe}_{2} \mathrm{O}_{4} /$ polypyrrole nanocomposite: A novel magnetic photocatalyst for degradation of organic dyes. Synth Met 267: 116459. https://doi.org/10.1016/j.synthmet.2020.116459

Oladipo AA, Ifebajo AO, Vaziri R (2018) Green Adsorbents for Removal of Antibiotics, Pesticides and Endocrine Disruptors. In: Crini G., Lichtfouse E. (eds) Green Adsorbents for Pollutant Removal. Environmental Chemistry for a Sustainable World, Springer, Cham: 19:327-351. https://doi.org/10.1007/978-3-319-92162-4_10.

Oladipo AA (2021) $\mathrm{CuCr}_{2} \mathrm{O}_{4} @ \mathrm{CaFe}-\mathrm{LDO}$ photocatalyst for remarkable removal of COD from high-strength olive mill wastewater. J Colloid Interface Sci 591: 193-202. https://doi.org/10.1016/j.jcis.2021.01.080.

Oladipo AA (2021) Rapid photocatalytic treatment of high-strength olive mill wastewater by sunlight and UV-induced $\mathrm{CuCr}_{2} \mathrm{O}_{4} @ \mathrm{CaFe}-\mathrm{LDO}$. J Water Process Eng 40: 101932. https://doi.org/10.1016/j.jwpe.2021.101932

Oladipo AA, Ifebajo AO, Gazi M (2019) Magnetic LDH-based $\mathrm{CoO}-\mathrm{NiFe}_{2} \mathrm{O}_{4}$ catalyst with enhanced performance and recyclability for efficient decolorization of azo dye via Fentonlike reactions. Appl Catal B Environ 243: 243-252. https://doi.org/10.1016/j.apcatb.2018.10.050.

Qasim M, Asghar K, Singh BR, et al (2015) Magnetically recyclable Ni0.5Zn0.5Fe2O4/Zn0.95Ni0.05O nano-photocatalyst: Structural, optical, magnetic and photocatalytic properties. Spectrochim Acta - Part A Mol Biomol Spectrosc 137: 13481356. https://doi.org/10.1016/j.saa.2014.09.039 
875

884

885 886

Roberts SC, Zembower TR (2021) Global increases in antibiotic consumption: a concerning trend for WHO targets. Lancet Infect. Dis. 21: 10-11. https://doi.org/10.1016/S1473$\underline{3099(20) 30456-4}$

Saranya J, Ranjith KS, Saravanan P, et al (2014) Cobalt-doped cerium oxide nanoparticles: Enhanced photocatalytic activity under UV and visible light irradiation. Mater Sci Semicond Process 26:218-224. https://doi.org/10.1016/j.mssp.2014.03.054.

Sathya B, Benny Anburaj D, Porkalai V, Nedunchezhian G (2017) Raman scattering and photoluminescence properties of $\mathrm{Ag}$ doped $\mathrm{ZnO}$ nano particles synthesized by sol-gel method. J Mater Sci Mater Electron 28:6022-6032. https://doi.org/10.1007/s10854-016$\underline{6278-3}$

Serna-Galvis EA, Berrio-Perlaza KE, Torres-Palma RA (2017) Electrochemical treatment of penicillin, cephalosporin, and fluoroquinolone antibiotics via active chlorine: evaluation of antimicrobial activity, toxicity, matrix, and their correlation with the degradation pathways. Environ Sci Pollut Res 24:23771-23782. https://doi.org/10.1007/s11356-017-9985-2

Sinha AK (2020) Band gap energy calculation of Cobalt doped Bismuth Ferrite Nanoparticles. In: Materials Today: $\quad$ Proceedings. 15: 15-1521. https://doi.org/10.1016/j.matpr.2021.01.912

Sivaranjani R, Thayumanavan A, Sriram S (2019) Photocatalytic activity of Zn-doped $\mathrm{Fe}_{2} \mathrm{O}_{3}$ nanoparticles: a combined experimental and theoretical study. Bull Mater Sci 42:185. https://doi.org/10.1007/s12034-019-1870-9

Thakur A, Kumar P, Thakur P, et al (2016) Enhancement of magnetic properties of $\mathrm{Ni}_{0.5} \mathrm{Zn}_{0.5} \mathrm{Fe}_{2} \mathrm{O}_{4}$ nanoparticles prepared by the co-precipitation method. Ceram Int 42: 10664-10670. https://doi.org/10.1016/j.ceramint.2016.03.173

Tran ML, Fu CC, Juang RS (2019a) Removal of metronidazole and amoxicillin mixtures by 
909

$\mathrm{UV} / \mathrm{TiO}_{2}$ photocatalysis: an insight into degradation pathways and performance improvement. Environ Sci Pollut Res 26: 11846-11855. https://doi.org/10.1007/s11356$\underline{019-04683-4}$

Tran ML, Nguyen CH, Fu CC, Juang RS (2019b) Hybridizing Ag-Doped ZnO nanoparticles with graphite as potential photocatalysts for enhanced removal of metronidazole antibiotic from water. J Environ Manage 252:109611. https://doi.org/10.1016/j.jenvman.2019.109611

Tsvetkov MP, Ivanova IR, Valcheva EP, et al (2019) Photocatalytic activity of $\mathrm{NiFe}_{2} \mathrm{O}_{4}$ and $\mathrm{Zn}_{0.5} \mathrm{Ni}_{0.5} \mathrm{Fe}_{2} \mathrm{O}_{4}$ modified by $\mathrm{Eu}(\mathrm{III})$ and $\mathrm{Tb}(\mathrm{III})$ for decomposition of Malachite Green. Open Chem 17:1124-1132. https://doi.org/10.1515/chem-2019-0116

Varma DM, Zahid MSH, Bachelder EM, Ainslie KM (2020a) Formulation of host-targeted therapeutics against bacterial infections. Transl. Res 220:98-113. 10.1016/j.trsl.2020.03.009

Varma KS, Tayade RJ, Shah KJ, et al (2020b) Photocatalytic degradation of pharmaceutical and pesticide compounds (PPCs) using doped $\mathrm{TiO}_{2}$ nanomaterials: A review. Water-Energy Nexus 3:46-61. https://doi.org/10.1016/j.wen.2020.03.008

World Health Organization, 2019: https://www.who.int/news-room/detail/29-04-2019-new-

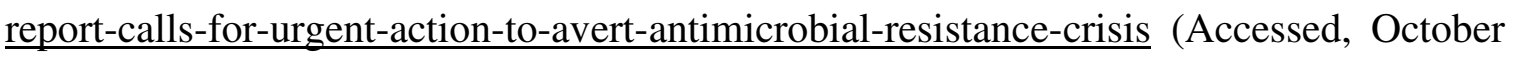
2020)

Yunhui Y, Xiangrong L, Tianjun N, Kaiwen C, Kun L, Qiying G (2019) In-situ grafting BiVO4 nanocrystals on a $\mathrm{BiPO}_{4}$ surface: Enhanced metronidazole degradation activity under UV and visible light. J Taiwan Inst Chem Eng 99: 82-92. https://doi.org/10.1016/j.jtice.2019.03.005

Zhao Z, Fan J, Deng X, Liu J, (2019) One-step synthesis of phosphorus-doped $\mathrm{g}_{-} \mathrm{C}_{3} \mathrm{~N}_{4} / \mathrm{Co}_{3} \mathrm{O}_{4}$ quantum dots from vitamin B12 with enhanced visible-light photocatalytic activity for metronidazole degradation. Chem Eng J 360: 1517-1529. 
https://doi.org/10.1016/j.cej.2018.10.23 